\title{
A FERTŐDI MARIONETTSZÍNHÁZ ÚJ ÉRTELMEZÉSE - AZ ÉPÜLETKUTATÁS („BAUFORSCHUNG”) ÉS ALAKHÜ FELMÉRÉS MINT KUTATÁSI MÓDSZER ALKALMAZÁSÁVAL
}

\author{
KRÄHLING JÁNOS* - HALMOS BALÁZS** - FEKETE J. CSABA***
}

A fertődi (a XVIII-XIX. századi névhasználat szerint eszterházai) marionettszínház és báboperajátszás az európai kastélykultúra jelentős attrakciója volt. Az építtető fóúr, Esterházy Miklós herceg mecenatúrája, valamint udvarának kiemelkedő müvészei és mesterei - Joseph Haydn és Karl Michael von Pauersbach - a marionettszínházat páratlan kulturális értékké tették hazánkban. Az 1772-73 között felépült színház pompáját és kialakításának egyediségét a korabeli utazók egybehangzóan elismerték. Az épület eredeti rendeltetését már a XVIII. század végén elvesztette, majd 1845 után több ütemben magtárrá alakították át, s a XX. században már a teljes pusztulás fenyegette. A helyreállítást célzó tudományos kutatás a Múemlékek Állami Gondnoksága megbízásából 2004ben kezdődött el. A helyszíni munka során alkalmazott „Bauforschung” módszer az épület legkisebb roncsolással járó részletes elemzését teszi lehetővé. Az alakhủ építészeti felmérés egyik tudományos eredménye, hogy bizonyította egy 1789-es átalakítási tervrajz azonosítását az épülettel. A falszövet, a festés- és vakolatrétegek és más nyomok alapos megfigyelése és rajzi dokumentálása lehetővé tette a marionettszínház átépítési periódusainak körvonalazását, továbbá az épület XVIII. századi - eredeti - tömeg- és téralakításának, homlokzatképzésének és fedélszerkezetének elvi rekonstrukcióját. A további kutatás - elsősorban a hitelesítő régészeti ásatások - a teljesen elpusztult gazdag belső dekoráció és a színpadtechnika történeti leírásokból ismert kialakításának bizonyítékait hozhatja felszínre.

Kulcsszavak: barokk építészettörténet, épületkutatás, Bauforschung, színházépítészet, marionettszínház

* egyetemi docens, a múszaki tudomány kandidátusa. BME Építészmérnöki Kar, Építészettörténeti és Múemléki Tanszék. 1111 Budapest, Múegyetem rkp. 3. K. II. 60. Tel.: 463-1330, fax: 463-1638; e-mail: krahling@et.bme.hu

** egyetemi adjunktus. BME Építészmérnöki Kar, Építészettörténeti és Müemléki Tanszék. 1111 Budapest, Müegyetem rkp. 3. K. II. 60. Tel.: 463-1330, fax: 463-1638; e-mail: halmos@et.bme.hu

*** egyetemi tanársegéd. BME Építészmérnöki Kar, Építészettörténeti és Múemléki Tanszék. 1111 Budapest, Múegyetem rkp. 3. K. II. 60. Tel.: 463-1330, fax: 463-1638; e-mail: fecsajo@freemail.hu 


\section{BEVEZETÉS}

A fertődi Esterházy-kastély marionettszínházának (1.ábra) kutatására a Budapesti Mủszaki és Gazdaságtudományi Egyetem Építészettörténeti és Müemléki Tanszéke 2004 decemberében kapott megbízást a Múemlékek Állami Gondnokságától. A megbízás azzal a kifejezett szándékkal jött létre, hogy a kutatás annak a módszernek az alkalmazásával történjen, amelyet a nemzetközi szakirodalom az általánosan elfogadott megnevezéssel ,Bauforschung”-módszernek ismer. ${ }^{1}$ A kifejezés nemzetközi megfelelői (angolul Building Archaeology, olaszul Archeologia dell' architettura, franciául Archéologie du bâti, hollandul Bouwhistorie) rendszerint tartalmazzák, ill. utalnak a „régészet” kifejezésre, amely a régészet egyes kutatási módszereinek az álló épület egészére való alkalmazását jelenti (de a régészeti kutatást természetesen nem helyettesíti). A hazai gyakorlat „épületkutatási” módszereiben a „Bauforschung”-tól lényegesen eltér. A fertődi marionett-

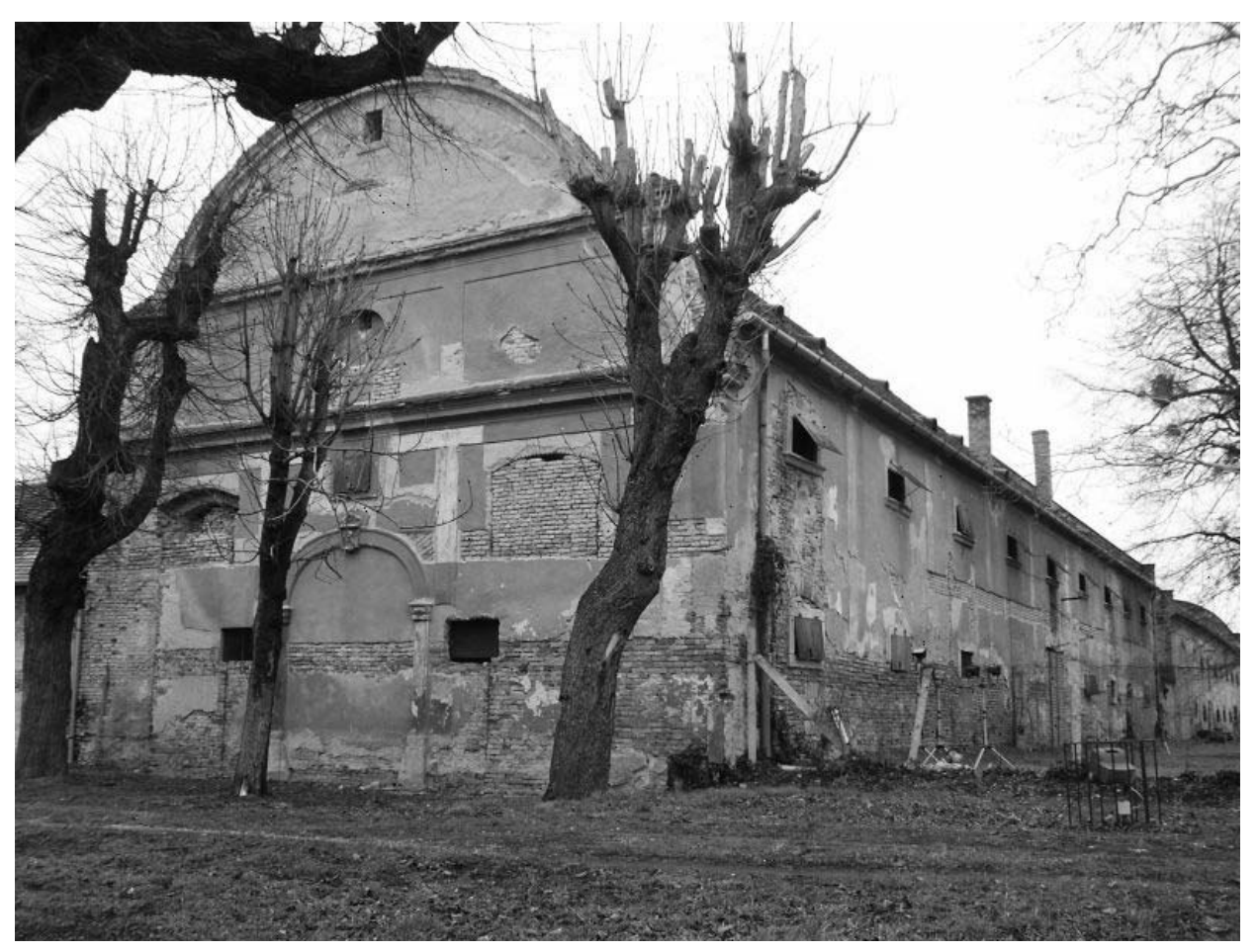

1. ábra. A fertődi marionettszínház mai állapotában

1 Manfred Schuller: Building archaeology. ICOMOS VII. Kiadja az ICOMOS, h. n. [München] 2002. p. 7. és az ottani 1. sz. jegyzet. 
színház alakhű felmérésen alapuló kutatásának részösszegzése érdekes lehetőséget biztosít a hazai kutatási módszerek és a Bauforschung módszereinek az összehasonlítására, mivel ezen az objektumon mindkét módszerrel történt vizsgálódás. ${ }^{2}$

A „Bauforschung”-típusú épületkutatást - és a továbbiakban az „épületkutatás” kifejezés alatt mindig ezt értjük - a módszer egyik kiváló múvelője, Manfred Schuller úgy definiálta, mint az építészettörténeti kutatás egyik sajátos kutatási módszerét, amelynek tárgya az épület története a lehető legtágabb értelemben, a müvészettörténet és régészet korszakbehatárolása nélkül. ${ }^{3}$ Ugyanezen diszciplínákkal szemben lényeges - és a hazai kodifikált épületkutatási gyakorlat vonatkozásában is döntő - különbség, hogy a „Bauforschung” mint épületkutatás legelső és elsődleges forrása maga az épület, és csak ezt követi minden egyéb történeti forrás és adat, lehet akár írott, akár képi formájú, ideértve a tipológiai, stíluskritikai megfontolásokat is. Ebből következik - és ez szintén lényeges különbség -, hogy az épületkutatás mindenekelőtt helyszíni kutatás, amelynek kérdésfelvetéseit és logikáját a történeti hitelességet szem előtt tartó megörzés-helyreállítás jelenti. ${ }^{4}$ Ezért a kutatás módszerei - ellentétben a hazai gyakorlattal - a lehető legkevésbé invazívak és roncsolásosak, a múemlék egészének, rangsorolás nélkül tekintett stílus- és formagazdagságának lehető legteljesebb megtartását tűzve ki célul. A roncsolásos vizsgálattal - falkutatás - szemben a restaurátor által végzett szondázásos módszerek használatosak, de rendszerint csak akkor, ha minden egyéb roncsolás nélküli vizsgálat - ideértve a modern természettudományos vizsgálatokat is - lezajlott. A dokumentálás során minden külsődleges (formai, felületi, színezési stb.) és belső (szerkezeti, anyaghasználatbeli, szerkesztési, funkcionális stb.) tulajdonsága lehetőség szerint hiánytalanul felismerendő, értelmezendő és rögzítendő. Ennek médiuma az építészek ősi és legalapvetőbb kommunikációs eszköze, a tervrajz. ${ }^{5}$ Természetesen az eddigi bevett gyakorlat szerint is a jó felmérés alapja a szakszerủ műemlékhelyreállításnak, ${ }^{6}$ de ott a rajz nem kutatási módszerként használatos. A pontos, ideális esetben az épület minden elváltozását egy adott, a kutatás időpontjában rögzítő építészeti felmérés alapján lehet az épület történetét tisztázni; ezért az épületkutatás alapja a pontos - bizonyos esetekben teljes egészében a helyszínen felhordott, ezért idealizáló elnevezéssel: ,„alakhü” - épületfelmérés. Az

2 A korábbi kutatásokat az ÁMRK részéről Somorjay Selysette végezte.

3 Manfred Schuller: Bauforschung. In: Der Dom zu Regensburg. Ausgrabung, Restaurierung, Forschung. Verlag Schnell \& Steiner, München-Zürich, 1990. (3. kiadás) pp. 168-223.

4 Gert Thomas Mader: Bauforschund und Denkmalpflege. In: Bauforschung und Denkmalpflege. Arbeitskreis Theorie und Lehre der Denkmalpflege E.V. Dokumentation der Jahrestagung 1987 in Bamberg. Bamberg, 1989. pp. 11-31.

5 Schuller 1990. i. m. p. 168.

6 D. Mezey Alice: A műemlékek helyszíni építéstörténeti feltárásának fontosságáról és tudományos feldolgozásuk jelentőségéről. Müemlékvédelmi Szemle 1999/1-2. sz. p. 12. 
alakhü felmérés metodikáját és a mindennapi müemlékvédelmi gyakorlatban való felhasználhatóságát az 1970-es évektől dolgozták ki és alkalmazták a német müemlékvédelmi gyakorlatban; használata ma már sok európai országban kiemelt kutatási-müemlékvédelmi feladatok esetében szinte kizárólagos . . A nagy időráfordítás miatt használata mindazonáltal korlátozott; különösen akkor javasolt, ha az épület deformálódott részeinek eltérő geometriája a datálás, a diagnosztika vagy esetleg az újonnan beépítendő eltérő geometriájú épületszerkezetek szempontjából fontos. ${ }^{8}$ Az alakhủ építészeti felmérés mint az épületkutatás alapmódszere abban különbözik leginkább a hazai gyakorlatban döntően alkalmazott felmérési vázlattal (manuáléval) ${ }^{9}$ készített felméréstől, hogy a mérés mindig az épülettől független vonatkoztatási rendszerhez történik, és szinte teljes egészében a helyszínen készül (ebben tér el lényegesen a szintén alakhü fotogrammetriai módszerektől), valamint a léptéke rendszerint nagyobb (1:25 vagy annál részletesebb). A helyszíni munkának azért nagy a jelentősége, mert a fotó alapján történő felhordás során sok lényeges információ veszhet el, leginkább azok, amelyek az épület lényeges szerkezeti, kronológiai, anyaghasználati stb. összefüggéseit tartalmazzák, és éppen ezért az épület történetének értelmezése szempontjából perdöntőek lehetnek. A helyszínen végzett alakhű felrajzolás egyúttal - a tégláról téglára való haladás léptéke miatt - interpretálási kényszert, állandó értelmezési feladatot jelent, amely minden más forráselemzést megelőz. A felmérés fontosságára és a magyar gyakorlat szerinti alkalmazására - mint a régészeti és falkutatás eredményeinek dokumentálására, továbbá ennek a rekonstrukcióhoz való viszonyára - vonatkozóan alapvető Feld István tanulmánya. ${ }^{10}$

A fertődi marionettszínház felmérése - az alakhủ építészeti felmérés szabályainak megfelelően - abszolút geometriai rendszer felvételével történt. Alapja lényegében egy háromdimenziós, derékszögű koordináta rendszer. Ez a geodéziai vízszintes-függőleges síkokra illeszkedik, és elméletileg az épülettől függetlenül felvehető, a gyakorlatban azonban a rendszer egyik tengelyét célszerü a felmérendő objektum valamely jellemző irányához igazítani. Esetünkben a kitúzött háló egyik tengelyének iránya a marionettszínház épületének hossztengelyével párhuzamos. A rendszer az egykori marionettszínház, narancsház és tiszttartói ház alkotta épületegyüttest összetartozó egységként kezeli, a belső udvart körülvevő épületek fel-

7 Mader i. m. p. 25.

8 Mader i. m. p. 24.

9 Hajnóczi Gyula: Müemlékfelmérés. Az Épitőipari Müszaki Egyetem Tudományos Közleményei. I. kötet 6. sz. Budapest, 1956.

${ }^{10}$ Feld István: Kutatás - dokumentálás - rekonstrukció. Müemlékvédelmi Szemle 1999/1-2. sz. pp. 27-56. Elfogadva tanulmányának gondolatmenetét és főbb állításait, nézőpontjaink különbségét ott látjuk, hogy értelmezésünk szerint az alakhü felmérés egyúttal a kutatás egyik lényeges eszköze, míg Feld István cikkében a felmérési rajz inkább dokumentációs eszköz, szakgrafika. 
mérése egyazon rendszerben készül. A felmérést segítő geodéziai kitűzés négy alappontja az épületegyüttes négy sarkán kívül helyezkedik el, ezek GPS-koordinátáikkal is adottak. ${ }^{11}$

A gyakorlati méréshez lényegében a hálóra illeszkedő vízszintes és függőleges síkok épületszerkezetekkel való metszését kell láthatóvá tenni. Ennek érdekében a hossztengelyeket és haránttengelyeket lézeres szintezőmüszerrel történt kitűzés után zsinórokkal rögzítettük a padlón és a falakon. A tengelyek távolsága a hossztengelyek esetében $2,6 \mathrm{~m}$, a haránttengelyek esetében $4 \mathrm{~m}$ volt. A főtengelyek távolságát esetenként az egyes épületszerkezetek pozíciójától függően módosítottuk, illetve segédtengelyek felvételére is szükség volt. Ezért ilyen felmérés esetén elengedhetetlen a tengelyrendszer felvételének megtervezése rajzban is, illetve a kitüzött tengelyek pontos dokumentálása léptékhelyes áttekintő rajzon (esetünkben a felmérés kitűzését 1:100 léptékben terveztük meg). ${ }^{12}$ A mértékadó magasság (a felmérés $\pm 0,00$ szintje) a magtárbejárat küszöbszintje volt. A külső és belső homlokzatokon a vízszintes síkokat ugyancsak zsinórokkal tüztük ki 1,5-2 m szintkülönbségekkel.

A felmérési rajzokat 1:20 léptékben vettük fel, egy-egy fötengely közötti szakaszt ábrázoló A3-as formátumú szelvényeken. Az alaprajzot - a magtárrá alakított állapotnak megfelelően - két szinten, a két magtárablak-sor magasságában ábrázoltuk, emellett elkészült valamennyi fal mindkét oldalának nézete, a belső falnézetek esetében a sarkokon a csatlakozó falak szélső axis-tengelyben felvett falmetszetével. A rajzok a helyszínen készültek, mért adatok alapján felszerkesztve, szabad kézi kidolgozással. A rajzi lépték által megkövetelt pontosság és az egyes részletek megfigyelésének ebből adódó alapossága hordozza magában az alakhelyes épületfelmérés valódi jelentőségét. A rajzok készítése közben részletesen és folyamatosan lehet ilyen módon rögzíteni a szerkezetekre, felületekre, anyagokra vonatkozó valamennyi fontos információt, melyeket rajzban és szöveges megjegyzésekkel is dokumentáltunk a lapokon. A rajzoló ilyen formán egy időben végzi az adott részlet felmérését és annak értelmezését. Az alakhelyes felmérés folyamata számos olyan információval szolgált számunkra, melynek alapján kijelölhető a szükséges restaurátori és régészeti feltárások helye. ${ }^{13} \mathrm{~A}$ barokk marionett-

${ }^{11}$ A fertődi kastélyegyüttes és a kastélypark geodéziai felmérését és az alakhủ felmérés alappontjainak kitűzését Gróf András geodéta végezte a Műemlékek Állami Gondnoksága megbízásából.

${ }^{12}$ A kitűzési tervhez alapdokumentációként a Győr-Sopron Megyei Tanácsi Tervező Vállalat 1988-ban készült hagyományos építészeti felmérését használtuk fel, melyet a Mủemlékek Állami Gondoksága bocsátott rendelkezésünkre.

${ }^{13}$ A régészeti feltárásra a Mủemlékek Állami Gondnoksága László Csabának és Koppány Andrásnak, az Állami Müemlék-helyreállítási és Restaurálási Központ munkatársainak adott megbízást, a - jelen tanulmány írása idején is zajló - helyszíni munkát Koppány András és Thúry László régészek vezetik. A restaurátori feltárást Lángi József végzi. 
színház esetében véleményünk szerint a megmaradt barokk vakolat is megőrzendő értéknek számít. Egy esetleges átépítésre, elfalazásra a vakolat vagy akár az azt fedő festékrétegek különbözőségéből is következtethetünk anélkül, hogy ezeket eltávolítva közvetlenül a falszövetet vizsgálnánk. A feltárások feladata itt elsősorban a hitelesítés, az épület fennálló állapotából leszűrhető feltételezések igazolása vagy cáfolása.

A felmérésben részt vettek a Budapesti Müszaki és Gazdaságtudományi Egyetem Építészmérnöki Karának, valamint a Corvinus Egyetem Tájépítészeti Karának hallgatói. ${ }^{14}$

\section{AZ ÉPÜLET KUTATÁSÁNAK TÖRTÉNETE}

A múvészettörténeti és építészettörténeti irodalom régóta elfogadott tényként tartja számon, hogy a fertődi épületegyüttesnek a főtengelytől keletre eső két magtárépülete azonos az egykori eszterházai marionettszínházzal és narancsházzal. Bár a marionettszínház kultúrtörténeti jelentősége is vitathatatlan, a szakma egészen a XX. század végéig adós maradt az épület kutatásával, ismereteit elsősorban az írott forrásokra alapozta. Ennek oka elsősorban az egykori színház múködő gazdasági funkciója volt, mely sokáig háttérbe szorította a mủemlékvédelmi szempontokat.

Az épületről a legutóbbi általunk ismert felmérést a Győr-Sopron Megyei Tanácsi Tervező Vállalat készítette 1988-ban. Az 1:100 léptékủ (és ennek megfelelő részletezettségü) hagyományos építészeti felmérés az egykori marionettszínházat és narancsházat, valamint a kettőt összekötő földszintes épületet ábrázolja alaprajzban, a két épület egy-egy keresztmetszetével, és az együttes négy homlokzatával. A felméréshez rövid múleírás is készült, mely az épület legfontosabb múszaki adatait, épületszerkezeteinek múszaki állapotát ismerteti. A dokumentáció magtár mivoltukban mutatja be az épületeket, nem célja a korábbi rendeltetésükre utaló nyomok bemutatása, elemzése. ${ }^{15}$

A mezőgazdasági funkció megszünése után röviddel az épület kutatásával Somorjay Selysette müvészettörténész foglalkozott, szakvéleményét 1992. au-

${ }^{14}$ A felmérési munkában jelen tanulmány szerzői mellett részt vettek: Gál Viktória, Havril Erika, Herczig Annamária, Horváth Balázs, Kiss Blanka, Lukács Bettina, Tamás Eszter, Pécsi Máté, Varga Tibor tájépítész hallgatók; Baracsi Gábor, Berényi Andrea, Bodnár Tibor, Cservenka Judit, Édes Zsuzsanna, Ekler Zsófia, Fábián Zsuzsa, Fássy Mónika, Fejér Judit, Gáspár Orsolya, Gyulovics István, Jászay Gergely, Kalcsó Kitti, Káplán Márta, Kemény Ágnes, Keresztessy Éva, Kiss Anna Sára, Koskóci Zsófia, Loszmann Dávid, Pataricza Kristóf, Szabó Angéla, Tóth Blanka Tímea, Urbanovics Bernadett építészmérnök hallgatók, valamint Veöreös András okl. építészmérnök.

${ }^{15}$ A dokumentáció a Múemlékek Állami Gondnoksága archívumában található. A felmérést és a hozzá tartozó műszaki leírást Antali Miklós okl. építészmérnök készítette. 
gusztus 31-i dátummal készítette el. ${ }^{16}$ A szakvéleményhez fotódokumentációt, korabeli ábrázolásokat, ${ }^{17}$ és vázlatos alaprajzot mellékelt. Utóbbi rajzon megkísérelte az épület egyes részeinek periodizációját, ${ }^{18}$ és jelölte az emeleti gerendafészkek (,falfülkék”) alaprajzi helyét. Szakvéleményében hangsúlyozta, hogy az elvégzett falkutatás az épület kutatása első lépésének tekintendő, szükségesnek tartotta további feltárások elvégzését. Ezért a szakvélemény - amelyet egy programtervhez kellett összeállítani a kutatási program befejezése elött - nem lehetett teljes, a rajzi feldolgozás és az eredmények alapos kiértékelése elmaradt. Később - anyagi források hiánya és a tulajdonos változása, valamint a program teljes leállítása miatt a kutatómunka félbeszakadt, folytatását már a szerző sem vállalta. ${ }^{19}$

A Kulturális Örökségvédelmi Hivatal tervtárában az épületre vonatkozó tervanyag nincs, illetve az ott található kevés tervlap nyilvánvalóan tévesen lett az épülethez rendelve. ${ }^{20}$ Megállapíthattuk, hogy magáról az épületről - Somorjay Selysette csírájában megszakadt múvészettörténeti kutatásán kívül - más dokumentált kutatás nem történt. Techikatörténeti szempontból lehet különösen érdekes Kaján Imrének az egykori barokk víztoronyról szóló publikációja. ${ }^{21}$

\section{EGY XVIII. SZÁZADI HERCEGI MARIONETTSZÍNHÁZ KÉPE ÉS XIX. SZÁZADI SORSA ESZTERHÁZA ÁBRÁZOLÁSOS ÉS ÍROTT ${ }^{22}$ FORRÁSAINAK TÜKRÉBEN}

„A ce mot de Marionettes, on n' imagineroit jamais que dut être quelque chose digne d'attention et de curiosité ... Erről a szóról: Marionette soha nem jutna eszünkbe, hogy méltó a kíváncsiságra és figyelemre, épphogy felocsúdtunk a meg-

16 „A fertődi Esterházy kastély egykori bábszínház épülete. Művészettörténeti Szakvélemény”. A dokumentum a Múemlékek Állami Gondnoksága archívumában található.

${ }^{17}$ A későbbiekben általunk is térgyalt „Beschreibung”-ban közölt helyszínrajz, valamint a „Prospekt nach dem Garten und Wald gegen Süden” feliratú látkép fénymásolata szerepel a dokumentációban. Utóbbiról megállapította, hogy nem ábrázolja helyesen a marionettszínház homlokzatát.

18 Az említett rajzon a falakon kétféle sraffozás szerepel, „mai állapot” és „,rekonstruált barokk kori állapot" megjelöléssel.

${ }^{19}$ Somorjay Selysette szóbeli közlése.

${ }^{20}$ A KÖH tervtárában 3090. leltári számon szereplő „Kiviteli tervdokumentáció a Növénynemesítési és Növénytermesztési Kutató Intézet Fertődi Gazdasága kazánház bővítésének műszaki kiviteli terveihez" címmel ellátott tervanyag valójában a kastélytól nyugatra álló egykori lovarda mellett létesítendő új épület terveit tartalmazza.

${ }^{21}$ Kaján Imre: Kutatási jelentés a fertődi Esterházy-kastély barokk víztornyának elméleti rekonstrukciójához. 2005. január 4. Megtalálható a http://www.dunamuzeum.hu weblapon.

${ }^{22}$ Munkánkban elsősorban a már publikált adatokra és ábrázolásokra támaszkodtunk. A bábszínházzal kapcsolatban jelenleg a MÁG megbízásából Bardi Terézia múvészettörténész folytat le- 
lepetésből, amelyet az előadások okoztak, s mindabból, amit eddig Eszterházán láthattunk. Az új múfajhoz ${ }^{23}$ készült teremdísz szintén a legritkább és legkitünőbb ízléssel készült. Az egész terembelső jobbra, balra kagylókkal, kis kavicsbarlangokkal volt borítva, melyek egy részében egy-egy kitűnően kidolgozott falra festett tájkép bújt meg, míg a többi kis szökőkutakat rejtett, melyek nagyon kellemes duruzsoló hangot adtak. A kavicsok csillogó porral voltak meghintve, melyek csodásan ragyogtak az őket megvilágító csillár fényétől. A herceg muzsikusai és színészei egy német operát adtak elő Philémon és Baucis címmel, Haydn múvét, ${ }^{24}$ kinek szép muzsikáját tapssal jutalmazták. A darab kimondottan erre az alkalomra készült, a színpadra alkalmazás és az előadás is természetes és keresetlen volt. De ami leginkább csodálatraméltó volt, az a díszítés szépsége, gazdagsága és kidolgozottsága. Az egész látvány és a különböző részek méretarányainak törvényszerüségét annyira hủen betartották, hogy így semmi sem veszett el az egész szépségéből. A függöny szétnyitásakor a következők tűntek föl: az Olimposz az összegyült istenekkel és folytatólagosan láthattunk még egy éjszakát, egy vihart, egy erdőt, egy vidéki tájat, a legszebben díszített palotabelsőt, végül az eszterházi park kertjeinek látképét, a legszebb és legtermészetesebb látszögből. A hitelességgel, pontossággal és gyorsasággal végrehajtott színváltozásokat a nézők tapsa, csodálkozása és meglepetése jelezte, hogy méltányolták. Volt az előadásnak egy olyan része, melyet nem szabad szó nélkül hagyni: amikor a díszítés egy templomot ábrázolt, akkor feltünt a csillárok között egy trófea, körülötte dicsfénysugarak, melyet az Igazság, az Óvatosság, a Báj, az osztrák uralkodóház címerei tartottak. E meggondolásból minden marionnette-figura magyaros ruhába volt öltöztetve, kik a földre borulva énekelték kórusban fenséges uralkodójuk magasztalását. Császárné Őfensége kegyeskedett megtapsolni az előadást, amely igen nagy tetszést váltott

véltári kutatásokat. Közléseit jelen tanulmányunkban is felhasználtuk, kutatása remélhetőleg további adatokkal segít hozzá az elvi rekonstrukció elkészítéséhez.

${ }^{23}$ Hazánkban a bábjátéknak minden társadalmi rétegben voltak hagyományai. Legrégebbi ezerkétszáz éves - változata, a pálcával mozgatott bábu (bunraku) japán eredetü. A XVII. században német vándorbábosok és mutatványosok előadásaival terjedt el Európában a felülről zsinórral mozgatott bábfigura (marionett). Végül a legfiatalabb változat a kesztyús bábú, a zsákbábú (burattino). (A Bábmúvészet születése. In: Magyar szinháztörténet 1873-1920. II. köt. Főszerk.: Székely György. Budapest, Magyar Könyvklub és OSZMI, 2001. p. 677.)

${ }^{24}$ Joseph Haydn (1732-1809) operáival nem bánt kegyesen az utókor. A vonósnégyesek vagy a szimfóniák, illetve a két nagy oratórium mellett azok hosszú ideig teljesen háttérbe kerültek. A tizenhárom fennmaradt olasz opera javarésze az eszterházai hercegi színházak számára készült, s így ezek voltaképpen soha nem lépték túl az eszterházai kastély kapuit. Külön csoportot alkotnak a báboperák (Philemon und Baucis, 1773; Der Hexenschabbas, 1773; Didone (Dido) abbandonata, 1776; Das abgebrannte Haus, 1773-79; Genovevens vierter Theil, 1777). 
ki, és amivel ő is rendkívül elégedettnek tűnt ..."25 Mária Terézia királynő 1773. évi eszterházai látogatását megörökítő leírásból a vendéglátó, Esterházy Miklós (1714-1790) herceg különleges pompájú marionettszínházának képe rajzolódik ki. Az Európában szinte páratlanul álló, semmihez sem hasonlítható marionettszínház-épület méltán keltette fel a korabeli látogatók, utazók, földrajztudósok figyelmét és elismerését: „Das Marionetten-Theater linker Hand im Garten, welches oblong mit ausserordentlichen feinem Geschmack angelegt worden und schon viel $1000 \mathrm{fl}$. Gekostet ... Annakutána van az úgynevezett marionettszínház a kertben, melynek épülete valamint költséges vala, úgy jeles, és gyönyörü is. A benne lévő ékesítések és rajzok, oly mesterséggel intéztettek Pauersbach ${ }^{26}$ feltalálója által, hogy hirtelenséggel harminchatszor változtathatok, $s$ jelesebb és tökéletesebb is vala, mint Parisban a híres Nikolaié. A »Masinák « megérdemlik, hogy az első »Masinisztától « ${ }^{27}$ láthatók legyenek, kik a bábokkal parodizált, énekes vígjátékokat, operákat adtak elő. A játékdaraboknak által változásait többnyire maga Pauersbach szerzette, a muzsikát hozzá pedig Haydn alkalmaztatta. A nézőknek helye egy kellemetes üreg-alkotmányt mutat, melyben a vízugrások azonnal elkezdődtek, mihelyt az Uraságok jelen valának ..."28

${ }^{25}$ Rélation des fetes données a sa Majesté L'Imperatrice, par S.A.M. le Prince d' Esterhazy, dans son Château d' Esterhaz. Le 1. et 2. 7-ber. Vienne, de l' Imprimerie Ghelen. 1773. (Kiadás és fordítás. In: Varga Kálmán: Mária Terézia Eszterházán. Budapest, MÁG, 2001. pp. 50-52.)

${ }^{26}$ A bécsi származású Karl Michael (Joseph) von Pauersbach (1737-1802) húsz éven át volt az eszterházai bábszínpad „szcenikusa" - szövegkönyvírója és színiigazgatója Albert Bienfait mellett. Méltatlanul elfelejtett alakja az 1761-től 1791-ig itt múködő Joseph Haydn zeneszerző, valamint az itáliai származású, 1771-1798 között Eszterházán alkotó díszlet- és jelmeztervező, Pietro Travaglia mellett a hercegi udvari opera- és bábjátszás meghatározója lehetett. (Balogh Géza: A bábjáték Magyarországon. In: A Napsugár fél évszázada. Békéscsaba, Békés Megye Képviselö-testülete, Megyei Művelődési Központja és Kézműves Szakiskolája, 1999. (Békési műhely); Pollheimer, Klaus: Karl Michael (Joseph) von Pauersbach (1737-1802). Das Leben und Werk des Begründers und Direktors des Marionettentheaters zu Eszterháza. In: Beiträge zur Theatergeschichte des 18. Jahrhunderts. Eisenstadt, 1973. pp. 34-78. (Jahrbuch für österreichische Kulturgeschichte, III. Band.)

${ }^{27}$ A marionettszínházról címủ esszéjében Heinrich von Kleist a báb súlypontjának mozgásvonaláról 1801-ben írta, hogy „... ez a vonal nem más, mint a táncos lelkének az útja, mely útra sehogy másként nem találhat rá a masiniszta, csak úgy, ha beleéli magát a marionett súlypontjába, más szóval: ha táncol". A masiniszta, azaz a bábos, a báb látszólag lelketlen mozgatója csak úgy tudja életre kelteni a figurát, ha ő maga lényegül át, azaz áttétetelesen neki magának kell táncolnia. S ez adja a kapcsolódási pontot az operával. Amennyiben a marionett valóban képes megjeleníteni a figurát, úgy a zenével összeforrva tudja kifejezésre juttatni annak sajátos érzésvilágát. Az ének és a zenekari játék színpadi megtestesülése a kleisti „masiniszta” által valósul meg. (Kleist, Heinrich von: A marionettszínházról. In: Kultusz és áldozat. Budapest, Európa Könyvkiadó, 1981. pp. 93-101.)

28 Johann Matthias Korabinsky: Geographisch. Historisches und Produkten. Lexikon von Ungarn. Pressburg, 1786. pp. 163-172. (Digitális közlése In. Mőcsényi Mihály: Eszterháza fehérenfeketén. Budapest, [1998.] CD-melléklet B03.) 
Eszterháza kastélyegyüttesére vonatkozó igen gazdag forrásanyag fontos csoportját képezik az ábrázolások, a művészettörténeti kutatások során már feltárt látképek (veduta), térképek és tervrajzok (delineatio). A XVIII-XIX. századi ábrázolások a kastély- és kertegyüttes kiépítéséhez kapcsolódnak, tárgyuk általában a rezidencia és környezete, a kastély és melléképületei, a kert és építményei, úthálózata, viszonya és szerkezeti kapcsolata a tájjal. Az ábrázolások - néhány építészeti tervlap kivételével - nem az egyes objektumok müszaki tervezését szolgálták, hanem hogy megjelenítsék egy-egy megvalósítandó épület, kertrész az együttes kompozíciós egységében betöltött majdani hatását. Általuk rögzítették a kastélyról és az egész együttesről a különböző megbízói és tervezői elképzeléseket, öntötték képi formába az újabb és újabb terveket, s örökítették meg az elkészült építményeket és részleteket. Mindez gyakran egyetlen ábrázoláson belül jelenik meg, így nem egyszer kibogozhatatlan viszonyt teremtve a tervezett, a részben megvalósult és a teljesen elkészült részek között. Az ábrázolások interpretációját ez teszi különlegesen nehézzé, amelyet csak növel, hogy - az ún. Pesci-féle olajképsorozat kivételével - rajtuk sem évszám, s gyakran múvészjelzés sem található. Az Eszterházaábrázolások - elsősorban az egymással összefüggő XVIII. századi képsorozatok dokumentumértékét és jelentőségét az adja, hogy nemcsak a kastélyegyüttes építéstörténetérôl szólnak, hanem Esterházy Miklós herceg személyiségének, mint egy barokk foúri mecénásnak önreflexiói. Eszterháza ábrázolásainak jelentős része sajnos elpusztult a második világháború végén, ugyanakkor néhány közülük leírásból vagy fotókópiáról ismert. ${ }^{29}$

Az ábrázolások sorában az elsők meglévő állapotot dokumentálnak. Egy nagyméretủ ma lappangó festmény fotókópiája ${ }^{30}$ (2. ábra) és egy, az ott ábrázolt kastély elrendezésének megfelelő erdőtérképlap ${ }^{31}$ ismert. Mindkettő jelzetlen, így többféle datálása is megjelenik a szakirodalomban, melyek közül a legfrissebb, a

${ }^{29}$ Galavics Géza: Eszterháza 18. századi ábrázolásai. Ars Hungarica, XXVIII. évf. (2000) 1. sz. pp. 37-71.

30 A festmény 1928. évi fotónegatívja ismert. In: Fertőd, Kastélymúzeum. Publ.: Hárich János: Eszterháza. I. Mütörténet. 1944. p. 9. (Kézirat, OSZK Kézirattár, Fol. Hung. 2151.); Bak Jolán: Néhány érdekes kép és festmény a fertődi kastélyról. Müemlékvédelem, XIX. (1975) 3. sz. pp. 184-186. 1. kép; Örsi Károly: Győr-Sopron megyei történeti kertek és az első, történeti kertekkel foglalkozó nemzetközi kollokvium. In: Magyar Müemlékvédelem, 1973-74. Budapest, 1977. pp. 285-286. 369. kép; Valkó Arisztid: Újabb adatok a fertődi (eszterházai) kastély építéstörténetéhez. Ars Hungarica, X. évf. (1982) 1. sz. pp. 75-84. 37. kép; Koppány Tibor, Dercsényi Balázs: Magyar kastélyok. Budapest, Officina Nova, 1990. p. 23.; Mőcsényi 1998. i. m. F03; Galavics i. m. pp. 39, 63. 1. kép; Mőcsényi Mihály: Eszterháza korszakai. In. Szerk: Alföldy Gábor. Királyi és hercegi kertek Magyarországon. Budapest, Mágus Kiadó, 2001. p. 205. 1. kép.

31 MOL S16 No 92. Publ.: Mőcsényi Mihály: Kritikus gondolatok és ismeretlen tények Eszterháza építéstörténetéhez. Soproni Szemle, 1997/1-2. sz. p. 98.; Mőcsényi 1998. i. m. D28-D31; Galavics i. m. pp. 44, 63. 6. kép; Mőcsényi 2001. i. m. p. 205. 2. kép. 


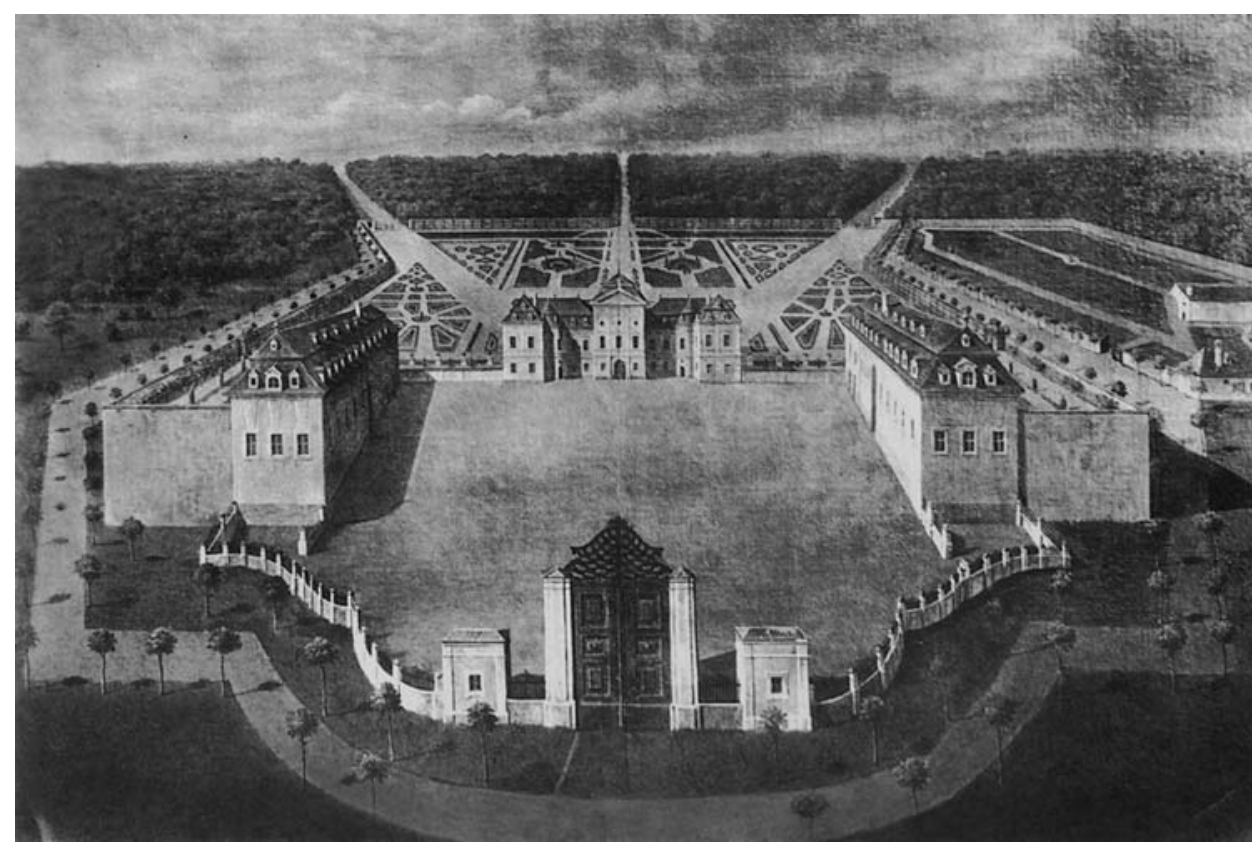

2. ábra. A kastélyegyüttes 1760 körül (1. a 30. jegyzetet)

Galavics Géza által meghatározott és indokolt időpont, az 1760 körüli évek fogadhatók el legvalószínúbbnek. ${ }^{32}$

A látképen a kastély északi irányból díszudvarával jelenik meg az épület mögött elterülő architektonikus kerttel, melynek déli határát s egyben a horizontot a Léserdő zárja le. A kastély keleti oldalán - a majdani marionettszínház és környező épületegyüttesének (víztorony, narancsház, tisztviselőház) helyén - az erdő ligetes, gyepes előtere épületek ábrázolása nélkül látható. Ugyanakkor a kastély nyugati oldalán kerítéssel határolt, két földszintes épülettel (talán kertészlak és üvegház) beépített haszonkert jelenik meg. Ezt tünik megerősíteni a már említett erdőtérkép, melynek sérülése miatt, igaz, a keleti rész hiányosan tanulmányozható.

A következő ábrázolást, egy jelzetlen, nagyméretű, lavírozott tollrajzot ${ }^{33}$ (3. ábra) a szakirodalom egyhangúan a kastélyegyüttes első nagy kiépítési üteme ,vezértervének" fogadja el, s 1762-re datálja.

32 Galavics i. m. p. 38.

${ }^{33}$ MOL T2 N 1560/1-4. Publ.: Balogh András: A fertődi kastély építéstörténetének főbb mozzanatai. Müvészettörténeti Értesitö, III. évf. (1953) 1-2. sz. pp. 130-133. 1. kép; Györ-Sopron megye müemlékei. I. köt. Sopron és környéke müemlékei. Írta: Csatkai Endre, Dercsényi Dezső. Budapest, Akadémiai Kiadó, 1956. p. 495. (Magyarország Múemléki Topográfiája II.); Mőcsényi Mihály: A fertődi táj-park-kastély müegyüttesről (IV.). Müemlékvédelem, XII. évf. (1968) 3. sz. p. 174.; 


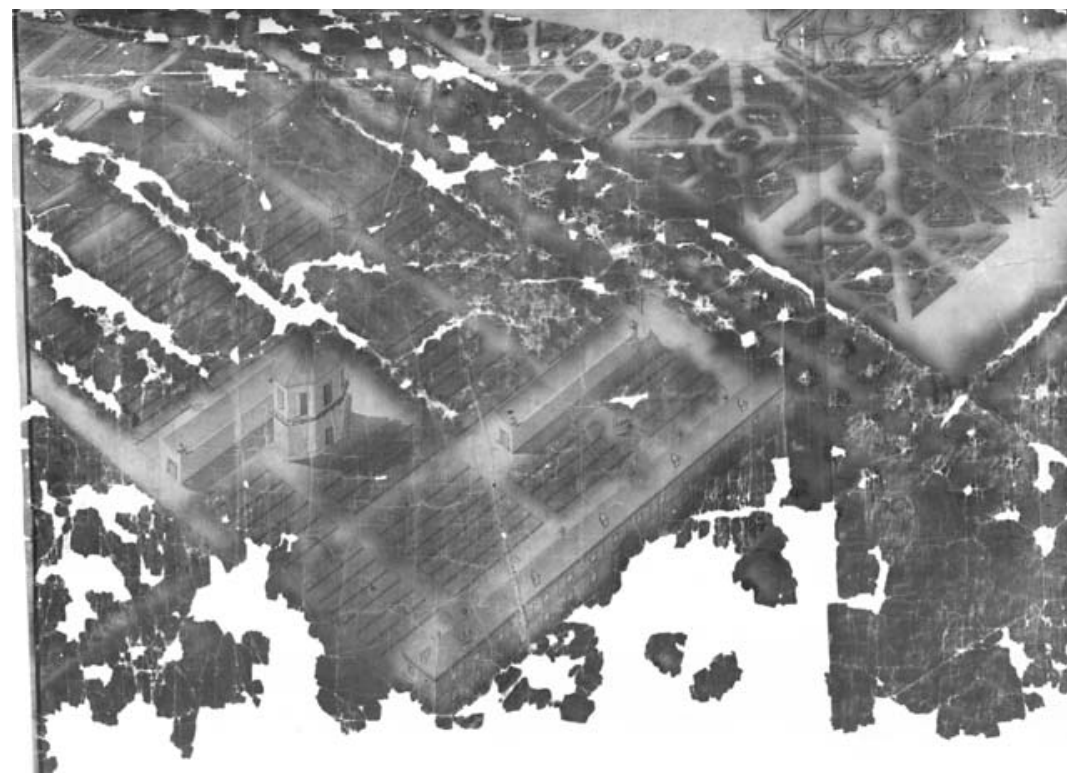

3. ábra. A kastélyegyüttes vezértervének részlete, 1762 körül (1. a 33. jegyzetet)

Az axonometriában ábrázoló, finoman kidolgozott rajz különböző építészeti és kertművészeti elemeket egyaránt biztonsággal megjelenítő mesterdarab. ${ }^{34} \mathrm{Az}$ újraformált kastélytól keletre fekvő - eddig üres területen - a rajz épületekkel benépesített, szabályos mezőkre osztott haszonkertet ábrázol. Északi határát egy keletnyugati irányú, hosszan elnyúló 15 axisos, egyemeletes, nyeregtetővel fedett egytraktusos épület zárja le, tengelyében nyíló kapuval. Az ágyások között két földszintes, délre tájolt üvegház helyezkedik el, ${ }^{35}$ közöttük, a kert keleti felében egy nyolcszögletes alaprajzú, egyemeletes, gúlatetős víztorony emelkedik, melynek emelete körül egy külső fa körfolyosó látható felvezető lépcsővel.

Axonometria a kastély- és kertegyüttes időben következő két ábrázolása is, de valójában ezek nem klasszikus madártávlati rajzok, hanem olyan térképek, ame-

Voit Pál: A barokk Magyarországon. Budapest, 1970. pp. 76-78.; Mőcsényi 1998. i. m. E01; Galavics 2000. i. m. pp. 41, 63. 3-4. kép; Mőcsényi 2001. i. m. p. 206. 3. kép.

34 Alkotójának Girolamo Le Bon-t (1700. k.-1765 u.), a bayreuth-i Szépmúvészeti Akadémia 1756-1761 közötti építészet és perspektíva tanárát, az ismert operaénekest és impresszáriót tartják. (Balogh i. m. pp. 130-133.; Horányi Mátyás: Eszterházi vigaszságok. Budapest, 1959. pp. 30-32.; Galavics 2000. i. m. p. 40.; Le Bon-ról 1. még Saur Allgemeines Künstler-Lexikon. Bd. 12., 1996. p. 449.)

35 Ilyen formájú üvegházak terveiből több is található az Esterházy-család budapesti hitbizományi levéltárából kiemelt tervek között. Pl. MOL T2 N 1475. 
lyek léptékhelyesen, síkban ábrázolják a területet, de azon belül az épületeket, kerti elemeket és növényeket térképjelek helyett, nézetükkel kiemelve és síkba forgatva jelenítik meg. Ezek a rajzok állnak legelöl azoknak a különleges, térképszerü Eszterháza-ábrázolásoknak sorában, amelyeket az évek során újra meg újra aktualizáltak, s az akkori állapotnak megfelelően, különböző formában és céllal többször is elkészítettek. A sorban az első egy „Ester-Has” feliratos, „Jacoby”36 által szignált rajz, ${ }^{37}$ melyet $1764-65$-re datálnak, ${ }^{38}$ s valamivel később, 1768-1772 között készülhetett a második, szintén Jacobynak tulajdonított, de jelöletlen ábrázolás. $^{39}$

Az egész együttes vonatkozásában a két rajz között számos eltérés mutatkozik, de a kastélytól keletre fekvő épületcsoport mindkettőn azonos formában szerepel. A terület északi határát adó - $\mathrm{s}$ az előzőekben is ábrázolt - egyemeletes épület itt 13 axissal, U-alakú formában jelenik meg. Középső íves záródású kapuja felett a főpárkányt törtvonalú oromzat koronázza, a szárnyépületek végét kerítés köti össze, melyen középen, dél felé egy kapu nyílik. Ez vezet a narancsház-víztoronymarionettszínház épületegyütteséhez, mely kis szabad térség mögött, az udvar teljes szélességében emelkedik szimmetrikus elrendezéssel. Középen a nyolcszögletủ víztorony egyemeletes és manzárdtetővel fedett. Jobb és bal oldalához egy-egy földszintes, 5-5 axisos, kontyolt manzárdtetős épület kapcsolódik. Homlokzatain karcsú, íves záródású nyílások jelennek meg, a középsők felett főpárkányra ülő íves oromzat látható.

Az együttest ilyen nyitott udvaros elrendezéssel mutatja az 1772. évi második nagy ünnepségre (Festin), vagy Mária Terézia 1773. évi látogatására készített színes, kétoldalas legyező alaprajzi ábrázolása ${ }^{40}$ (4. ábra), melyet valószínúleg Jacoby rajza után Ferdinand Landerer (1730-1795) metszett rézbe.

A szakirodalom szerint ez Eszterháza korabeli állapotának leghitelesebb ábrázolása, mivel a képeket hordozó legyezőket az ünnepség résztvevőinek osztogatták, s funkciója az volt, hogy segítse a tájékozódást a parkban. Így joggal feltételezhető, hogy ebben az estben inkább a valós állapotokat kívánták ábrázolni. ${ }^{41}$

\footnotetext{
${ }^{36}$ Nicolaus Jacoby (1733-1784) francia (építész)mérnök 1756 óta állt Esterházy Pál Antal (1711-1762), majd haláláig Miklós herceg szolgálatában. (Balogh i. m. p. 133.)

37 Österreichische Nationalbibliothek, Kartensammlung, Alb. 202-212. Wien. Publ.: Galavics 2000. i. m. pp. 46, 63. 7. kép; Mőcsényi 2001. i. m. p. 206. 5. kép.

${ }^{38}$ Galavics 2000. i. m. pp. 44, 63-64.

39 Fertőd, Kastélymúzeum. Publ.: Galavics 2000. i. m. pp. 47, 64. 8. kép; Mőcsényi 2001. i. m. p. 208. 6. kép; Varga i. m. pp. 31, 32.

${ }^{40}$ OSZK, Színháztörténeti Tár ltsz. 552416/a-b. Publ.: Balogh András: A „Magyar Verszália" építője. Müemlékvédelem VI. évf. (1962) 1. sz. pp. 110-111. 4. kép; Mőcsényi 1998. i. m. 110; Galavics 2000. i. m. pp. 50-51, 65. 11-12. kép; Mőcsényi 2001. i. m. p. 210. 9. kép.

${ }^{41}$ Galavics 2000. i. m. p. 48.
} 


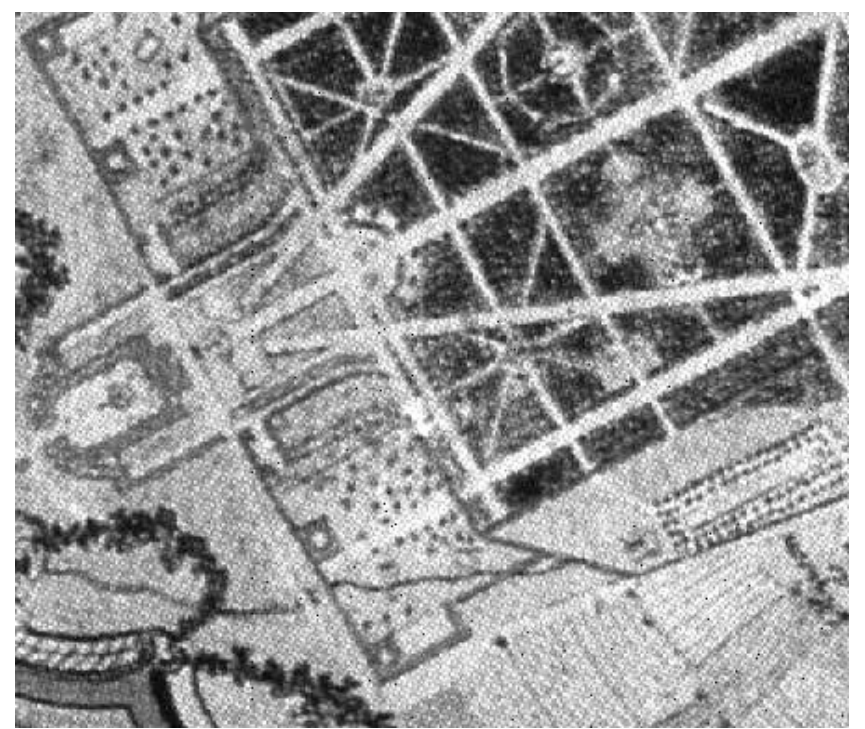

4. ábra. Ünnepi legyezőn ábrázolt helyszínrajz részlete, 1773 körül (1. a 40. jegyzetet)

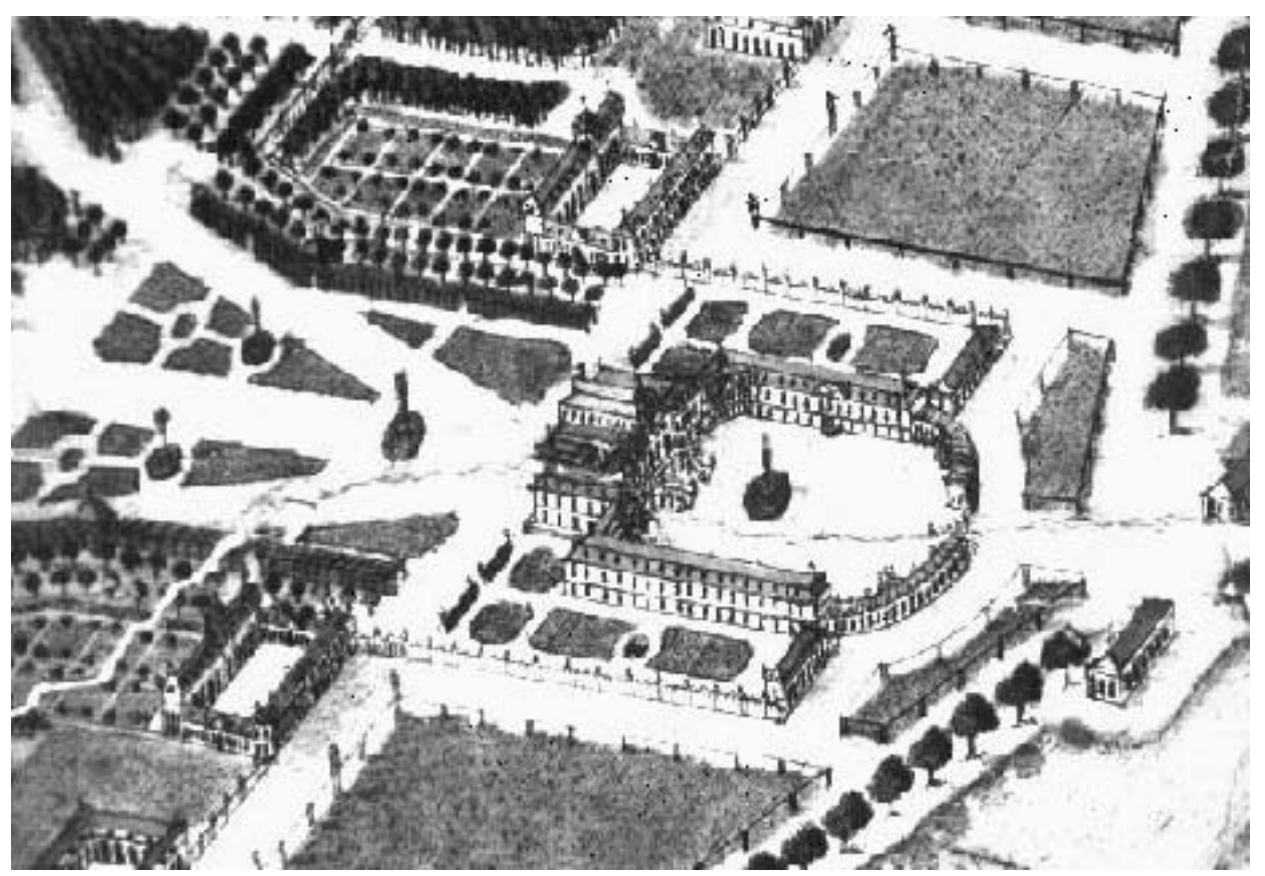

5. ábra. Színes rajz, madártávlati kép, 1775-76-ból (1. a 42. jegyzetet) 
Néhány évvel Mária Terézia látogatása után, talán 1775-76-ban egy újabb Eszterháza-ábrázolás ${ }^{42}$ (5. ábra) készült el. Az ismeretlen rajzoló axonometriában mutatta be az együttes megújított formáját.

A korábbiakhoz képest számos változást és eltérő részletet mutató ábrázolás a marionettszínház és épületcsoportjában is mutat újdonságot. Az együttes zártudvaros formában szerepel, melyet a 13 axisos északi épület földszintes szárnyépületeinek a narancsházzal és a marionettszínházzal való összekötése eredményezett. A korábbi, fallal elválasztott és kapuval átjárhatóvá tett két udvar így egyesült, $\mathrm{s}$ ide vezet a $6+1+5$ axisos mellékszárnyon nyíló íves kocsibehajtó kapu is. Figyelemreméltó változás a narancsház és a marionettszínház háromaxisos véghomlokzatainak törtvonalú, oromfalas kialakítása, melynek három pontját szobor díszíti, továbbá a földszintes oldalszárnyak bekapcsolódása miatt udvari homlokzataik 44 axisossá váltak. A manzárdtetőkön korábban ábrázolt félköríves oromzatok helyett itt a homlokzati nyílásokhoz rendezett 4-4 tetőablak figyelhető meg.

Eszterháza látképei közül az 1779-80-ban készült négydarabos olajfestménysorozat mindig is különös figyelmet kapott a szakirodalomban. Esterházy Miklós az 1770-es évek legvégén már joggal érezhette, hogy hercegi rezidenciája igazán ekkor lett méltó a megörökítésre, s Itáliából Gaetano Pesci látképfestőt ${ }^{43}$ hivatta udvarába. A kastélyt a négy égtáj felől ábrázoló festménysorozat közül csak az 1780-ban készült déli látkép ${ }^{44}$ maradt fent.

Az ábrázolt látvány hitelességéről a szakirodalomban szélsőségesen megoszlanak a vélemények. A kétséget az ébreszti, hogy a Pesci-kép az 1779. november 18án leégett operaház helyén 1780-ra felépült nagyobb, új operaház keleti homlokzatát úgy ábrázolja, hogy szemben - a marionettszínház helyén - ennek teljesen szimmetrikus megfelelőjét tünteti fel, noha ez utóbbi sohasem létezhetett.

Miklós herceg néhány év múlva eszterházai kastélyáról és kertjéről illusztrált német nyelvü leírást készíttetett úgy, ahogy ez európai fejedelmi udvarokban szokás volt. A leírást illusztráló képekkel az együttes látványos bemutatására törekedett. Az 1784-ben megjelent Beschreibung... ${ }^{45}$ látképeit a Pesci-féle festmények,

${ }^{42}$ Fertőd, Kastélymúzeum. Publ.: Mőcsényi 1997. i. m. pp. 11, 16.; Bugár-Mészáros Károly: Fertődből Eszterháza. Szalon II. évf. (1998) 1. sz. p. 5.; Mőcsényi 1998. i. m. E06; Galavics 2000. i. m. pp. 53, 65. 13-14. kép; Mőcsényi 2001. i. m. p. 209. 7. kép.

43 Bartolommeo Gaetano Pesci (1749-1783 u.) egy bolognai múvészcsaládból származott, tagja és tanára volt a nagy múltú bolognai Accademia Clementinának, s valószínűleg testvére, Antonio Pesci révén került 1779-ben Eszterházára, aki az itteni operatársulat énekese volt. (Galavics 2000. i. m. pp. 55-56.)

${ }^{44}$ KÖH-MÉM ltsz.: 75.11.1. Publ. többek között: Galavics 2000. i. m. pp. 55, 65. 17. kép; Möcsényi 2001. i. m. p. 212. 11. kép.

${ }^{45}$ [Primitivius Niemitz] Beschreibung des hochfürstlichen Schlosses Eszterház im Königreiche Ungern. Pressburg, 1784. № 1-6. kép. (Modern közlése: Mőcsényi 1998. i. m. CD B09.) 
térkép- és alaprajzait Jacoby rajzai után Ferdinand Landerer metszette. A mellékletek között az első az egész együttes alaprajzát térképszerüen ábrázoló lap.

A térkép ábrázolása és magyarázata szerint a „K” az „Opernhaus” és a „T" jelű „Marionetten Theater und Orangerie” egymással szimmetrikusan szemben, azonos alaprajzi elrendezéssel láthatók: ,Stehet dem Opernhause gegenüber, und ist ziemlich geräumig, jedoch ohne Logen, und Gallerie...” - „Az operával szemben áll a tágas, de páholyok és karzat nélküli Bábszínház. Földszinti nézőtere barlanghoz hasonló; a falak, benyílók és nyílások különféle lépcsőkkel, kagylókkal és csigákkal vannak díszítve..." A telepítés ábrázolásában feltűnő, hogy a zárt udvarból a narancsház tömbje kelet felé - aszimmetrikusan - kinyúlik, s így jelölt az operaház is. Ez a narancsház esetében megfelel a valóságnak, de az új operaház esetében - mint a XIX. századi kertalaprajzok tanusítják - nem.

Eszterházára a Beschreibung megjelenését követően - utoljára a XVIII. században - 1784-85-ben hívtak újra festőt. A minden bizonnyal egy bécsi festő által készített öt lapból álló gouache-képsorozatból mára kettő fényképének üvegnegatívja maradt fent. Az egyik Eszterházát távolról, a sarródi út felől nézve ábrázolja. ${ }^{46} \mathrm{~A}$ látképen jól látható a kastélytól keletre húzódó tisztviselői ház és a hátterében meghúzódó víztorony manzárdteteje.

Az 1772 és 1785 közötti ábrázolások áttekintéséből az valószínüsíthető, hogy a marionettszínházat és épületegyüttesét egy alkalommal - talán épp az operaház és a kínai táncház leégésével összefüggésben - átalakították. Az átalakítás legfőbb momentuma az addig nyitott udvar zárttá tételében és ennek építészeti vonzataiban határozható meg.

A XVIII. századi ábrázolások sorában az eszterházai színházakra vonatkozó építészeti tervrajzok különleges fontossággal bírnak. Az új operaház tervrajzpublikációja (alaprajz, több metszet (6. ábra), homlokzat) a Beschreibungban jelent meg 1784-ben.

Erre az épületre vonatkozik az a szignálatlan és datálatlan átalakítási tervrajz ${ }^{47}$ (7. ábra), amelynek felirata szerint - ,Entwurff zu stärkerer Heizung des Hochfürstl: Opern Hauses zu Esterhaz" - a hercegi operaház erősebb fütésének kialakítása volt a célja. A tervrajz „A” jelöléséből arra lehet következtetni, hogy ez egy alternatíva első változata, s párja, a „B” jelü tervrajz ${ }^{48}$ (8. ábra) - melynek felirata: „Entwurff zu einem Fürstl: Winter Theater in Esterhaz” - szerint, mint másik lehetőség, egy korszerü téli színház kialakításának lehetősége is felmerült.

46 Üvegnegatív. In: Iparmüvészeti Múzeum adattára, Budapest. Publ.: Balogh 1962. i. m. p. 109. 2. kép; Galavics 2000. i. m. pp. 62, 68. 25. kép.

${ }^{47}$ MOL T2 $\mathrm{N}^{\circ}$ 1222. Publ.: Horányi 1959. i. m. 22. ábra.

${ }^{48}$ MOL T2 N 1223. Publ.: Horányi 1959. i. m. 23. ábra; Mőcsényi 1998. i. m. CD D60. 


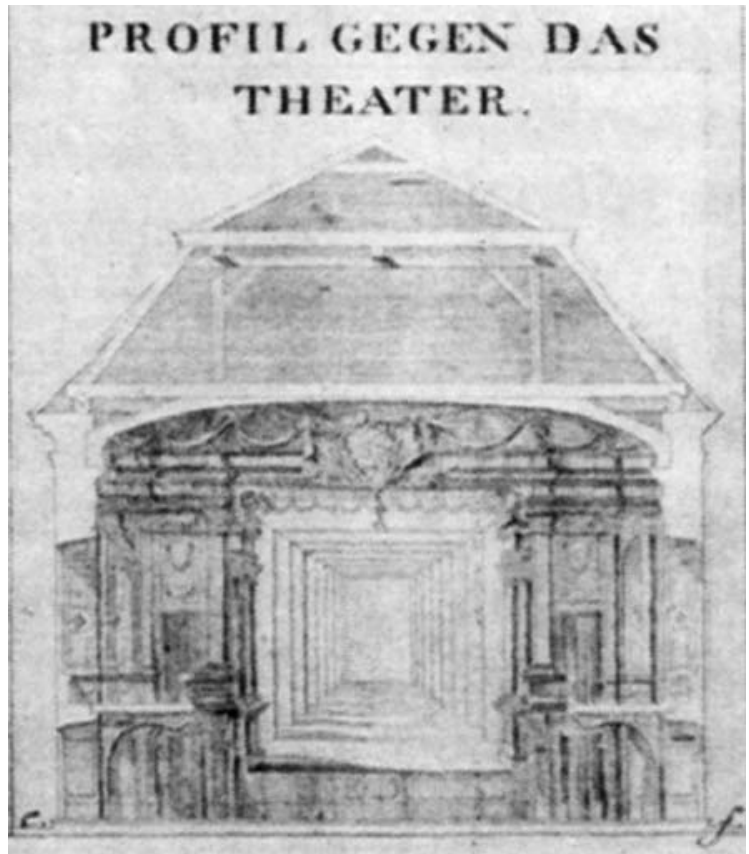

6. ábra. Az új opera metszete a „Beschreibung”-ból

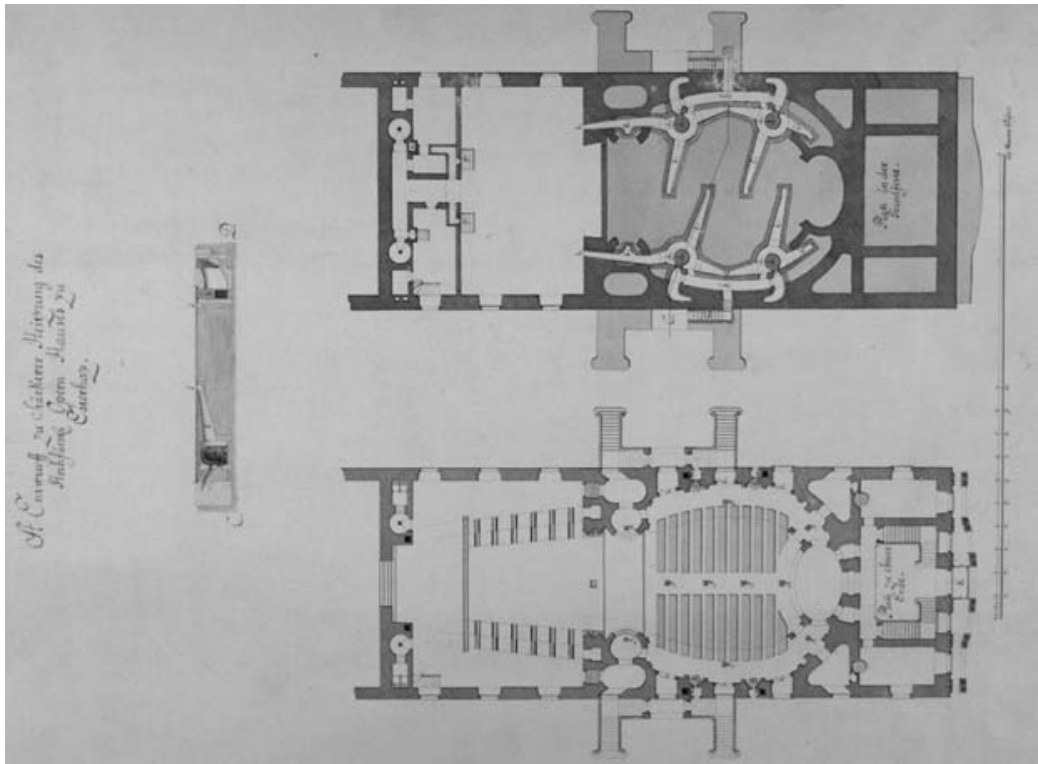

7. ábra. Az 1789-es átalakítási terv „A” változata - az opera fütésének kiépítése (1. a 47. jegyzetet) 


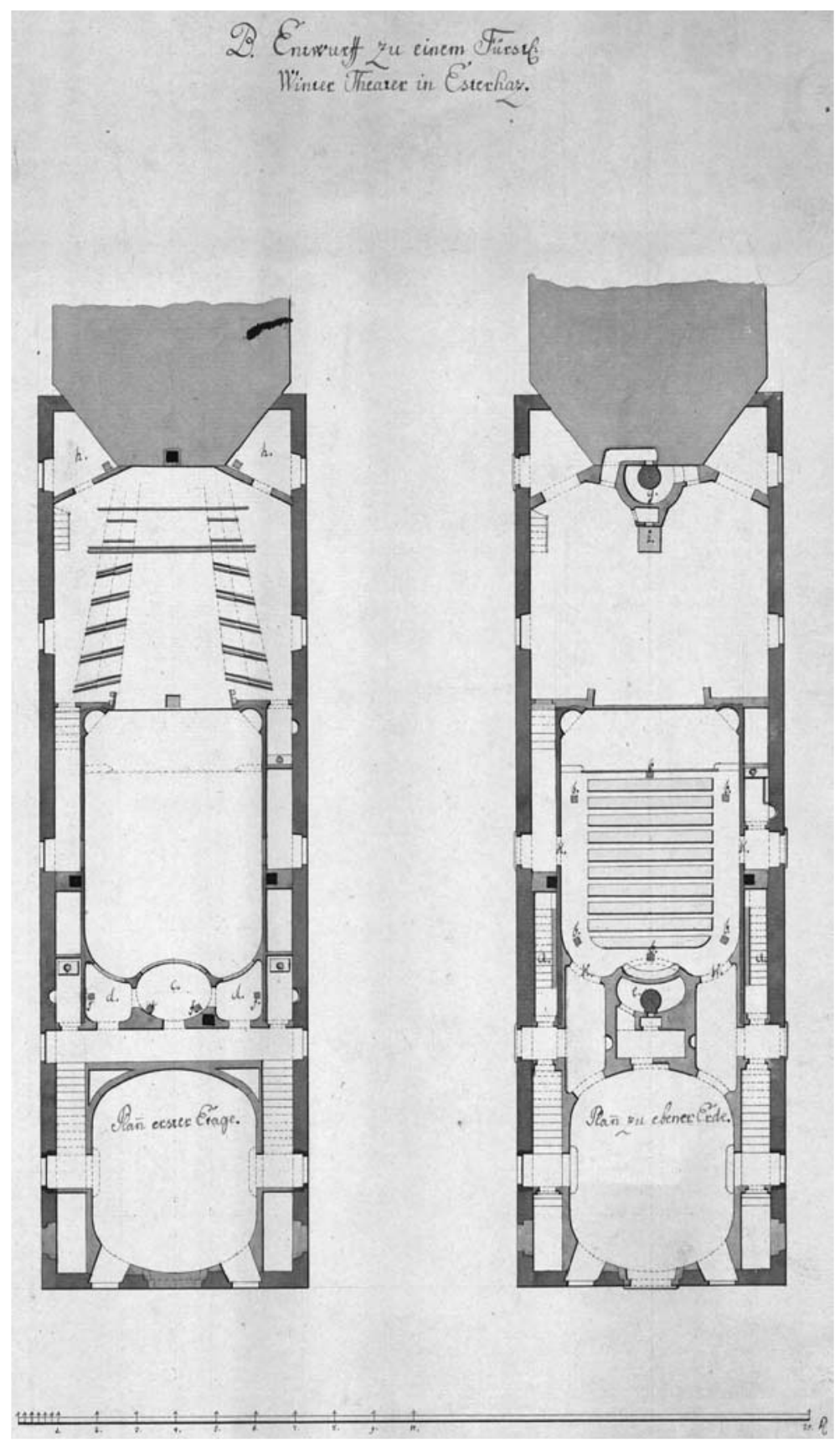

8. ábra. Az 1789-es átalakítási terv „B” változata - téli színház kialakítása (1. a 48. jegyzetet) 
Előbbi alternatíva az újonnan elkészült operaház alagsorának kisebb átalakítását, míg a második változat egy meglévő épület szinte teljes átalakítását jelentette. Ez utóbbi épület egy nyolcszögletes toronyhoz kapcsolódó, hosszoldalán 5, rövidebb oldalán 3 axissal kialakított épület, melynek terében a rajz megtartásra érdemes színpadperspektívát, proszcéniumnyílást és két oldalán egy-egy hosszfalhoz is kapcsolódó falfülkét, valamint előtte sekély zenekari árkot jelölt. Mivel a két átalakítási rajz keletkezése 1784 és 1790 közé datálható ${ }^{49}$ az eszterházai együttesben ekkor ilyen adottságokkal rendelkező épület csak a marionettszínház lehetett. Joggal feltételezhető tehát, hogy a hercegi marionettszínház és belső terének egyetlen máig ismert alaprajzi ábrázolása a „B” jelú átalakítási terv sötétszürke színnel jelölt része. E feltételezést az is erősíti, hogy a tervlapon kibontakozó épület aránya, nyílásritmusa és kapcsolata a nyolcszögletủ toronnyal a látképeken 1764 óta tervként, majd megvalósultként ábrázolt épülettömeggel jó összhangban áll. ${ }^{50}$

Esterházy Miklós herceg halálával nemcsak a közép-európai késő barokk egyik legjelentősebb mecénása távozott, hanem véget ért Európa-szerte az az életforma is, amely a barokk fóúri kultúrát életre hívta és éltette. 1791 után Miklós fia, Esterházy Antal (1738-1794), majd ennek utódai már nem az eszterházai rokokó kastélyegyüttes pompás keretei között kívántak élni, mely így elindult a pusztuláshoz vezető lassú átalakulás útján. A XIX. századi ábrázolások erről a folyamatról tanúskodnak.

Az első fontosabb XIX. századi térképábrázolást ${ }^{51}$ (9. ábra) Szakonyi Ignác 1845-ben készítette az egzotikus fák faiskolájának áttelepítési terveként.

A térkép ábrázolásán a marionettszínház és épületcsoportja még XVIII. századi alaprajzi (tömeg)formájában a középső toronnyal áll. Megváltozott hasznosításáról viszont már 1824-ből megjegyezték, hogy „, a játék-szinekben széna tártatik..." 52

49 A tervek 1784 elé azért nem datálhatók, mivel a Beschreibung operaalaprajzán a korszerüsítendő fütési rendszer szerepel; Miklós herceg 1790. évi halála után az átalakításoknak pedig már nem volt indoka. A rajzok elkészülésének pontos dátumára (Joseph Ringer soproni építőmester, 1789. dec. 28.) és a hozzá tartozó iratokra - amelyen valóban szerepel a marionettszínházra való utalás Velladics Márta a MOL-ban végzett kutatásai, az Esterházy hercegi tervtár iratanyagának rekonstrukciója során talált rá. Segítségét és az adatok utólagos rendelkezésre bocsátását ezúton is köszönjük.

${ }^{50}$ Meg kell jegyezni, hogy a B-jelű, ún. Entwurff-alaprajz és alakhű felmérésünk digitális összevetítéséből az tünik ki, hogy az 1780-as évek végi ábrázolás a mai - valós - épület kontúrjánál keleti irányban hosszabb alaprajzot mutat.

51 A herceg Esterházy-család fraknói levéltára. Baupläne N 332. Alföldy Gábor tájépítész kutatása és szíves közlése. Feldolg.: Alföldy Gábor: Eszterháza parkja a XIX-XX. században. Tud. Dok. II. 2003-2004. (Gépirat, MÁG.)

${ }^{52}$ Utazásbeli Jegyzetek Óvárról, Kismartonról, Fraknóról, s Eszterházáról. Tudományos Gyüjtemény, 1824. III. k. pp. 40-56. 


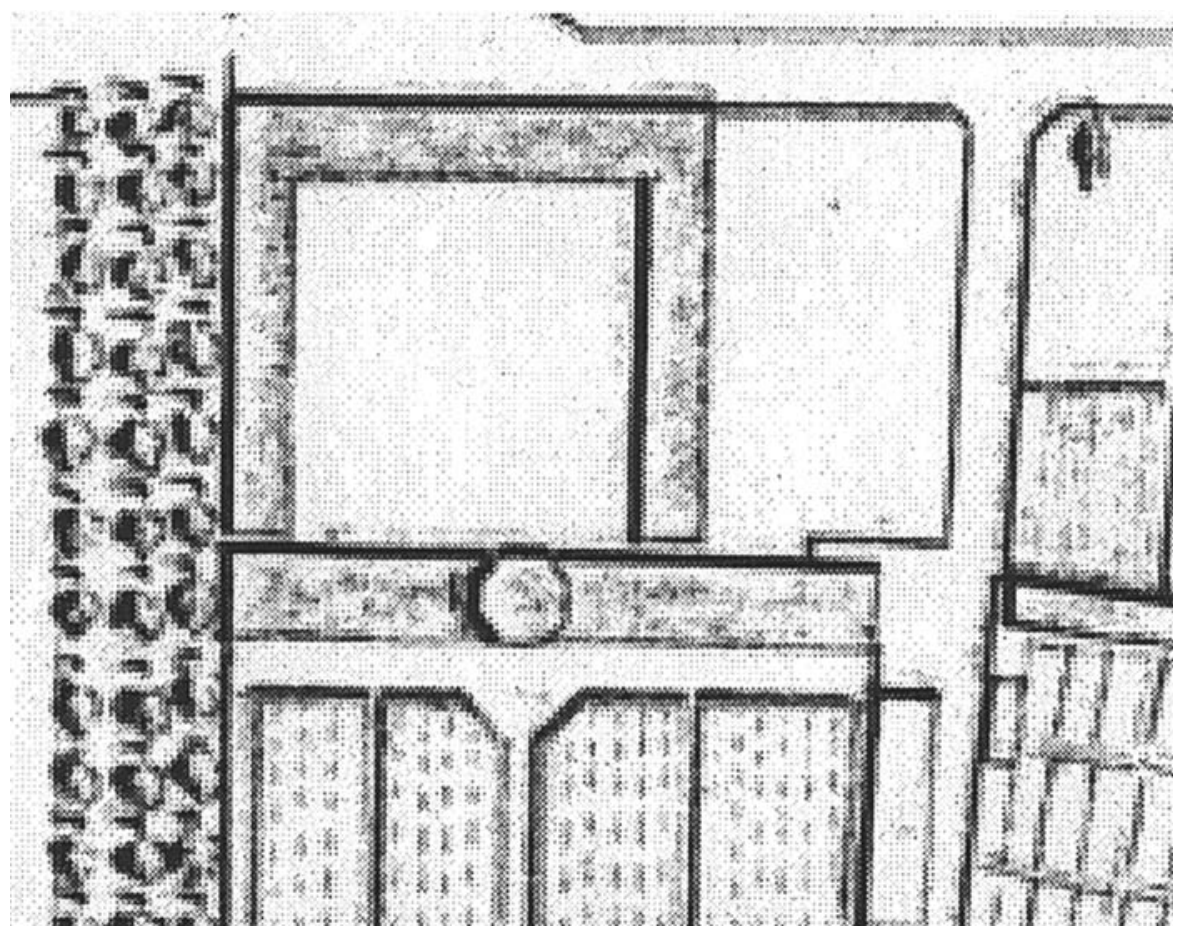

9. ábra. Kertépítészeti terv 1845-ből (1. az 51. jegyzetet)

A XIX. század második felének - elsősorban a birtokrendezéshez, -felméréshez és kertátalakításokhoz kötődő kataszteri vagy kéziratos térképein az épületcsoportot úgy ábrázolják, hogy tömegében vagy épületkontúrjában nem állapítható meg egyértelmü változás. A Molnár Károly által 1865 elött rajzolt térképen ${ }^{53}$ az sejthető, hogy a marionettszínház és a narancsház közötti torony már nem áll, vagyis az épületeken jelentős változás (átalakítás) történt.

A jelentősen megváltozott, torony nélküli állapotot egyértelmúen ábrázoló - és egyben az első XX. századi - térképet ${ }^{54}$ Anton Umlauft 1903-ban készítette el az új angolkert és északi park kialakításának tervezése során. Ez a terv a század eleji nagy kastélyrestaurálási és kertátalakítási munkálatok része lehetett, mely időszakhoz további ábrázolások is köthetők.

\footnotetext{
${ }^{53}$ A herceg Esterházy-család fraknói levéltára. Karten N 317. Alföldy Gábor tájépítész kutatása és szíves közlése. Feldolg.: Alföldy 2003-2004. i. m.

${ }^{54}$ Bundesgärten, Schönbrunn, Planarchiv, $N^{\circ} 351$. Alföldy Gábor tájépítész kutatása és szíves közlése. Feldolg.: Alföldy 2003-2004. i. m.
} 


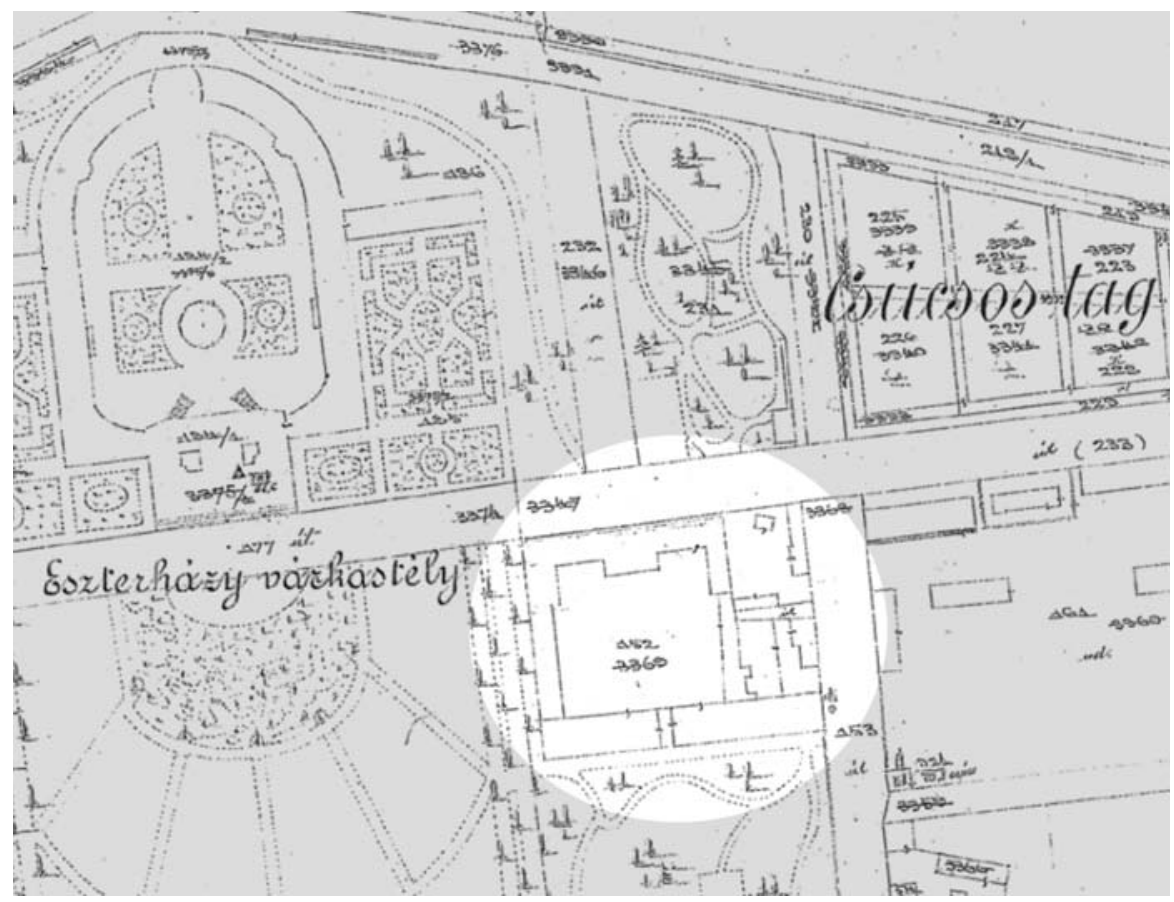

10. ábra. Kataszteri térkép 1907-ből (1. az 55. jegyzetet)

Eszterháza kataszteri térképe ${ }^{55}$ (10. ábra) 1907-ben készült el, s vele egyidős és szintén Nagy Miksa uradalmi mérnök munkája lehet a keleti épületcsoport részletes építményleltára és felmérési rajzdokumentációja ${ }^{56}(11-12$. ábra) is.

A felmérési dokumentációban $\mathrm{N}^{\circ} 4$ számon ,granárium" (magtár) elnevezéssel a volt marionettszínház épülete azonosítható, mely ekkor már teljesen átalakított formájában állt. Az épületet a keleti oldalon kontyolt tetővel látták el, belsejét fa terménytároló födémekkel több szintre osztották, s e födémeket két sorban elhelyezett 8-8 db fa pillérrel támasztották alá. A szintekre vezető lépcső az épület közepére került. A földszinti alaprajz nyílásrendje teljesen újszerü, a keleti részen - a torony helyén - széles nyílások láthatók; az emelet magtárablakai viszont még követik az 5-5 tengelyes megnyitást. ${ }^{57}$

55 Eszterháza kataszteri térképe, 19. [4] szelvény, 1907. Felmérte: Nagy Miksa. M 1:2880 [1914. évi változásokat rávezette: Goda László] FÖMI Budapest.

${ }^{56}$ Az Esterházy Süttöri uradalom épületleltára. Nagy Miksa, 1907 k. 4. granárium alaprajzai. A herceg Esterházy-család fraknói levéltára. Prot. 6091. Alföldy Gábor tájtervező kutatása és szíves közlése.

${ }^{57}$ Az 1907. évi alaprajzot digitális eszközökkel az 1780-as évek végi, ún. Entwurffalaprajzzal összevetítve az látható, hogy az épületkontúr jó közelítéssel azonos, tehát az 1907. évi 


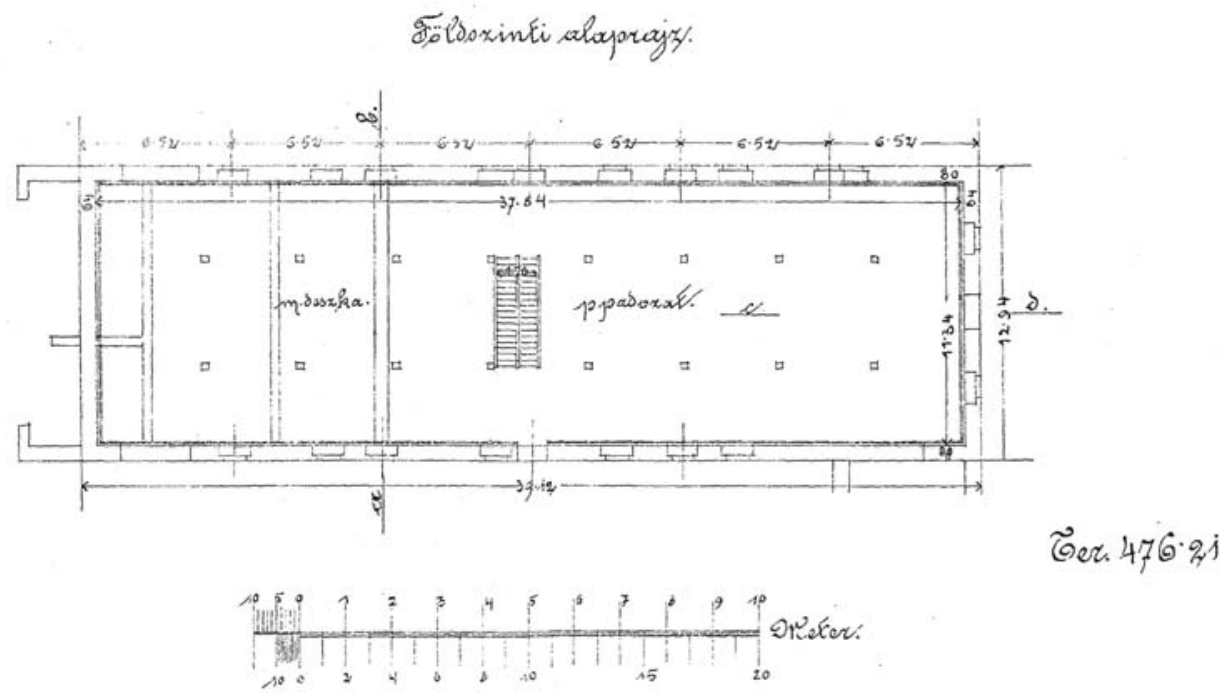

11. ábra. A magtár 1907-es felmérése, földszinti alaprajz (1. az 56. jegyzetet)

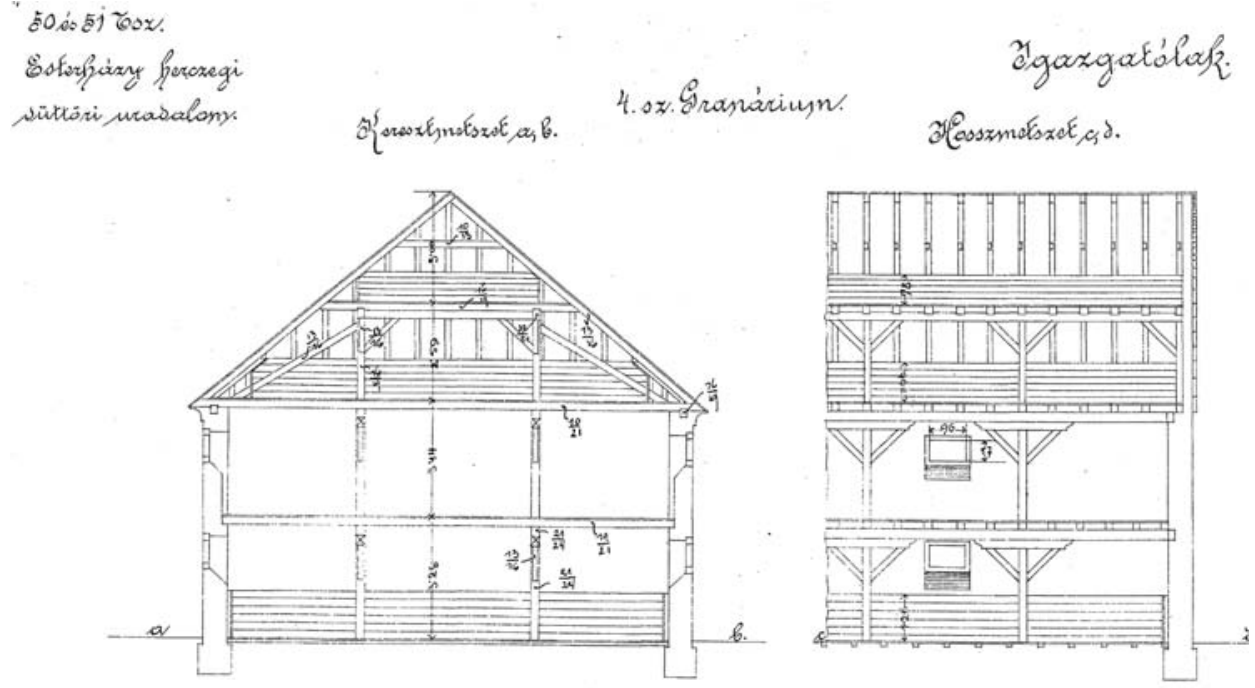

12. ábra. A magtár 1907-es felmérése, metszetek (1. az 56. jegyzetet) 


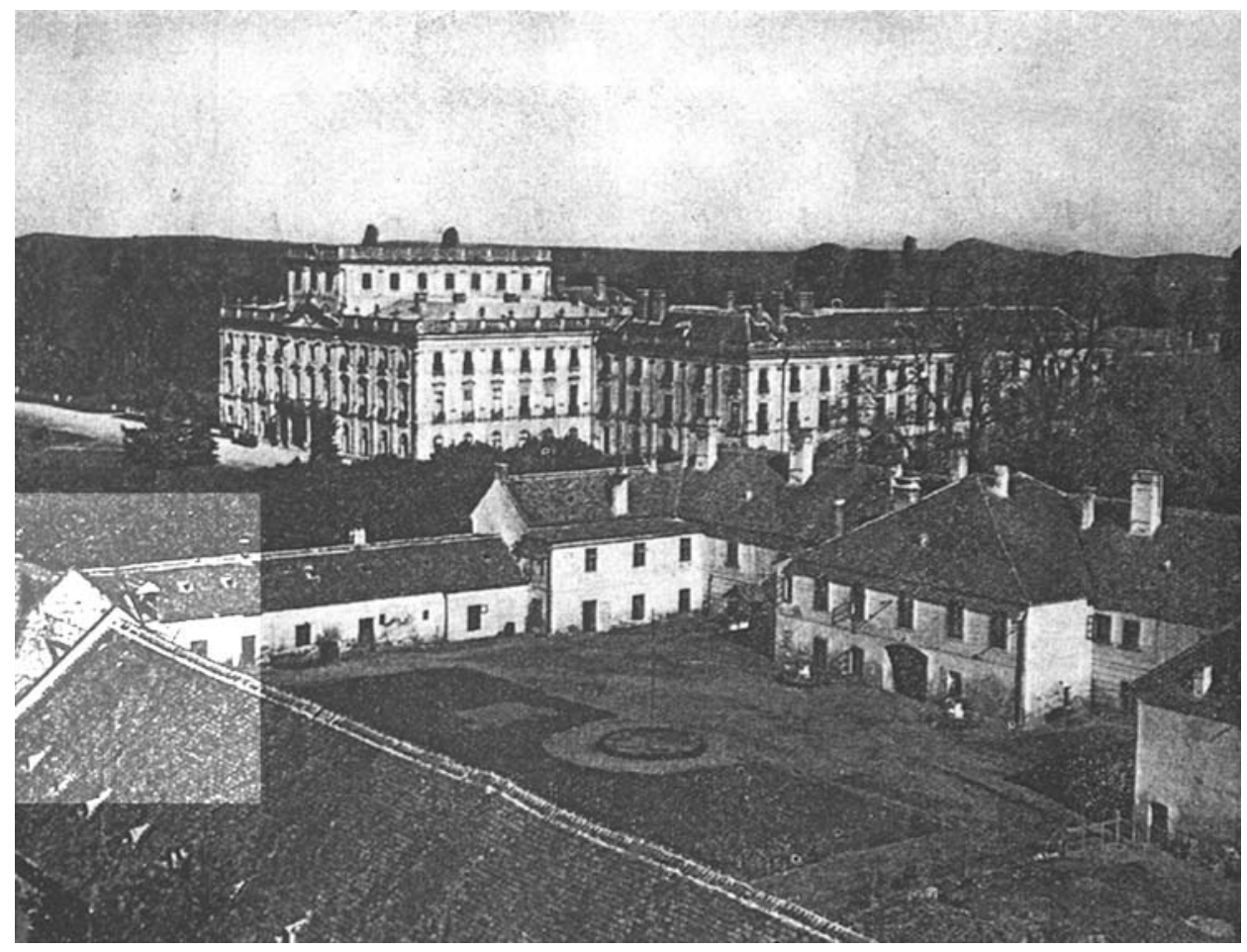

13. ábra. Az épületegyüttes az 1950-es években (1. a 60. jegyzetet)

1945 után az épülettömböt további átalakítások és csonkítások érték, melyekről az 1965. évi kataszteri térképen ${ }^{58}$ túl számos fényképfelvétel is tanúskodik. ${ }^{59}$ Bizonyos az is, hogy 1907 és 1956 között a magtárat jelentősen átalakították, mivel mai keleti oldala oromfalas ${ }^{60}$ (13. ábra), belső pilléreinek száma pedig mindkét sorban $10-10 \mathrm{db}$.

Az 1773 előtti ábrázolások áttekintéséből - és az eddigi történeti kutatások vonatkozó megállapításaiból - az eszterházai marionettszínház felépítésének kezdete 1764 és 1772 közé tehető. Esterházy Miklós herceg Karl Michael von Pauers-

rajz - a földszint viszonylatában - sincs a mai épületkontúrral fedésben. A két épület nyílásritmusa a rajzokon megközelítően sem azonos, jól látható viszont a lebontott torony helyén utóbb épített XIX. századi falak elrendezése. Ezek a falak ma hiányoznak, de bekötésük az északi és déli hosszfal belső oldalán jól azonosítható.

${ }^{58}$ Fertőd, kataszteri térkép részlete, 1965. Körzeti Földhivatal, Kapuvár.

${ }^{59}$ A 11. képet közli: Csatkai--Dercsényi 33. jegyzetben i. m. p. 497. 494. kép; továbbá pl. Mőcsényi 1998. i. m. CD E0101, E0102, E0104.

${ }^{60}$ L. az 1956-ban közölt fotót, 13. ábra. (Csatkai-Dercsényi i. m. p. 497. 494. kép.) 
bachtól 1772. július 23-án vásárolta 300 dukátért a marionettszínházat ${ }^{61}$ azzal a feltétellel, hogy az eszterházai új színházat vezetnie is kell. ${ }^{62}$ Esterházy herceg egyik 1773. évi leveléből ${ }^{63}$ tudjuk, hogy a kishöflányi (Kleinhöfflein) hegyekről kagylót gyüjtetett, melyeket a kis színház grottájához jóknak talált, $\mathrm{s}$ ha még több kellene, újabbak gyüjtetését is tervezte. Az 1773-as év levéltári anyagaiban rendszeresen ,új” marionettszínpadról beszélnek, ${ }^{64}$ ugyanis az újonnan elkészült marionettszínházban 1773-ban, Mária Terézia királynő látogatása alkalmából rendezték meg az első előadást, Haydn Philemon és Baucis c. báboperájának bemutatásával. ${ }^{65}$ Ez volt Magyarországon az első állandó, nagyszabású építészeti koncepcióval megvalósuló fớri magánszínház, ${ }^{66}$ mely bábszínpadával Európában is szinte páratlanul állt. ${ }^{67}$ A kortársak részletes leírásaiból megtudjuk, hogy barlangszerü belső terének csigákkal, kagylóval, gipszstukkóval gazdagon kialakított felületei

${ }^{61}$ Landon, H. C. Robbins: Das Marionettentheater auf Schloss Eszterház. Österreichische Musikzeitschrift 26 (1971) Heft 5/6. p. 274.

${ }_{62}$ Pollheimer i. m. pp. 38, 39.

${ }^{63}$ Mőcsényi 1998. i. m. CD a585. Forrás: MOL. Fasc. 1533. 1773. júl. 10.

${ }^{64}$ Landon 1971. i. m. p. 274.

${ }^{65}$ Horányi közvetett bizonyítékai a marionett építésének 1773-as dátumára: 1. Az 1773-as Mária Terézia-látogatás kapcsán említik először; 2. Az első ismert marionettopera a Philemon és Baucis, amelynek előjátéka a Götterrath; 3. M. Ernst, az egyházi kórus egykori tagja 1805-ben egy fizetésemelési kérelem kapcsán említi, hogy eszterházai ténykedését 1773-ban a marionettszínházban mint alténekes kezdte; 4. A Preßburger Zeitung az 1773-as Mária Terézia-látogatás kapcsán írja, hogy a Philemon és Baucis „Marionettenoperette”-t egy egészen új színpadon (,,auf einer ganz neuen Bühne”) adták elő. (Landon 1971. i. m. p. 274.; Horányi 1959. i. m. alapján).

${ }^{66}$ Az 1760 előtti időkből vannak ugyan források, melyek szórványos (alkalmi) színházi előadásokról tudósítanak (Holics, 1746-47, 1749, 1756; Kismarton, 1749, 1755, 1762; Nagykároly, 1757, 1792; Nagyvárad, 1765-66, 1776; Varasd, 1768, 1770), de ezek mindegyike a kastély egyik nagyobb termének alkalmi színpadán, fơuri múkedvelők részvételével zajlottak. Bővebben 1 . Staud Géza: Magyar kastélyszínházak. 1-3. k. Budapest, Színháztudományi Intézet, Országos Színháztörténeti Múzeum, 1963-1964. (Színháztörténeti könyvtár 11, 14-15.)

${ }^{67}$ A fóúri színház az abszolutizmus korának távolról sem valami szórványos, hanem nagyon is általánosan elterjedt jelensége, mely egész Európában megtalálható. Az olasz, francia, német, lengyel és cseh kastélyszínházak mellett a XVIII. századi Habsburg Birodalomban is mozgalmas kastélyélet bontakozott ki, s ezen belül jelentős szerepet játszottak a fóuri színházak. Osztrák területen a Habsburg-ház laxenburgi (1682), schlosshofi (1725-29) és schönbrunni kastélyszínházai mellett ott találjuk Auersperg herceg bécsi magánszínházát, a Lichtenstein hercegek feldsbergi (1719k.) és eisgrubi (lednicei 1846-58), vagy a Thurn-Taxis hercegek regensburgi színházát. Cseh- és Morvaországban a Schwarzenberg hercegek, Chotek grófok és más arisztokraták kastélyaiban folyó színielőadások ékes bizonyságai a rokokó fơuri színházi divatjának. Ugyanezt példázzák a csehországi Náchod (1634 k.), Veltrusy (1716-1764), Český Krumlov (1680-82, 1765-66), Jaroměřice nad Rokytnou (1700-1737), Litomyšl, Kačina (1806), a prágai Traun- és Waldstein-paloták vagy Németországban például Gotha $(1681-83,1775)$ kastélyszínháza is. Ezek között marionettszínházat csak kis számban találunk, pl. Bécs-Schönbrunn (1774 u.) vagy Lindau (1782) kastélyában. 
elsősorban természeti formákat idéztek, s mint ilyen jellegü dekoráció színvonalas példája lehetett az ún. grottensaal-architektúrák európai képviselőinek. ${ }^{68}$

Az 1773-tól 1775-ig terjedő időszakban a hercegnek nem volt állandó marionett-társulata. Erre az a Rahiernek címzett, 1773. március 13-án kelt levél is utal, amelyben a herceg - miután tudomására jutott, hogy Haydn kis marionettszínházzal bír - arra utasítja a jószágkormányzót, hogy szervezzen hitvesének a születésnapját megelőző estére Haydnnal egy kis meglepetést. ${ }^{69}$

A marionettszínház virágzását 1775-1778 közöttre tehetjük, ekkor Karl Michael (Joseph) von Pauersbach volt az igazgató. Megjegyzendő, hogy Pauersbach korábban szerzőként, színpadtervezőként, nem állandósított igazgatóként szerepelt. Távozása után 1779-ben mindössze egy, 1783-ban pedig ismét egy új darabot adtak elő. ${ }^{70}$

Az 1780. év színházi és operaévadja Eszterházán februárban kezdődött, és novemberig tartottak rendszeresen előadásokat. Mivel az operaház az előző évben leégett, a színmúveket és operákat az ideiglenesen erre a célra átalakított marionettszínházban tartották. A marionett-előadások tartására egy ideiglenes kerti épületet állítottak. ${ }^{71}$

Pompakedvelő Miklós herceg halála után csaknem minden zenészt és színészt elbocsátottak, mivel a következő herceg, Antal új udvartartást vezetett be. Az utolsó nagy ünnepség 1791 augusztusában, Sopron megyei föispánná való kinevezésének tiszteletére történt, ekkor a „Venere e Adonis” címü operát adták elő Joseph Weigl irányításával (mivel Haydn nem tudott a herceg kérésének eleget téve Angliából visszatérni erre az alkalomra), a bécsi udvari operatársulat énekeseivel. ${ }^{72} \mathrm{~A}$ marionettszínház ekkorra már nem éledt újjá, az egykorú tudósítás szerint magyar táncot adtak elő benne. ${ }^{73}$

A későbbiekben, mikor II. Miklós birtokul kapta a majorátust, Eszterháza már igen elhagyatott volt. Travaglia és a kosztümöket varró „garderobière” azt a feladatot kapta, hogy vigyázzon a színházi kellékekre. 1796 júliusában II. Miklós megparancsolta, hogy minden régi, használhatatlan díszletet szállítsanak kocsikon

${ }^{68}$ Például Salzburg-Hellbrunn, 1613-16; Versailles, 1665; Vöröskő, 1680 k.; Bécs-Belvedere, 1715; Potsdam-Neue Palais, 1756-63.

${ }^{69}$ Landon 1971. i. m. p. 274.

${ }^{70}$ H. C. Robbins Landon: Haydn's Marionette Operas and the Repertoire of the Marionette Theatre at Esterház Castle. In: The Haydn Yearbook. Vol. I. (1962) Theodore Presser Company, Bryn Mawr in association with Universal Edition, Wien etc. p. 122.

${ }^{71}$ Hárich, János: Das Repertoire des Opernkapellmeisters Joseph Haydn in Eszterháza (1780-1790). In: The Haydn Yearbook. Vol. I. (1962) Theodore Presser Company, Bryn Mawr in association with Universal Edition, Wien etc. p. 25.

${ }^{72}$ Landon 1962. i. m. p. 123.

73 Színházi hírek 1780-1803. Magyar Színházi Intézet, Budapest, 1982. pp. 70-74. (Színháztörténeti Könyvtár 13.) 
a Fertő-tóhoz és ott mossák át, hogy azután majd Kismartonban használhassák, ahol az operaélet folytatását - jóval szerényebb léptékben - tervezte. A színpad és díszletraktárak kiszellőztetéséről, az eszközök összeírásáról is rendelkezett, amelyek közül a javíthatóakat Kismartonba szállíttatta. ${ }^{74}$

A színpadot és a színpadgépezetet lebontották és nagy részét szintén Kismartonba szállították, majd 1799 januárjában az egész díszletraktárat megszüntették. Klutsewsky (más írásmód szerint Klutscheszky) grófnő megvásárolta azokat a kosztümöket, amelyekre Kismartonban nem volt szükség, ${ }^{75}$ és az ekkor már nyugdíjba vonult Travaglia felügyelte a kosztümök és marionettek szállítását; a grófnő 1000 forintot fizetett az egész szállítmányért. ${ }^{76}$

Később, 1803-ban a marionettszínházban vadászfegyvereket tároltak, majd 1824-ben marháknak való takarmányt, egy 1832-es adat szerint pedig faraktárként szolgált. ${ }^{77}$ A Tudományos Gyüjteményben 1824-ben már mint szomorúsággal teli épületet említik. $^{78}$

A XIX. és XX. század eleji ábrázolásokat áttekintve látható, hogy a barokk marionettszínházat a későbbi gazdasági felhasználás következtében, 1845 után a víztorony lebontásával egy ütemben magtárrá alakították át, majd ezzel a rendeltetéssel élte meg a XX., illetve szinte a teljes pusztulástól fenyegetve a XXI. századot is.

\section{A MARIONETTSZÍNHÁZ LEÍRÁSA}

Az épület leírását a mai állapotnak megfelelő rendszerben közöljük, és a jobb azonosíthatóság kedvéért a rekonstrukció esetében is egyes épületelemekre így hivatkozunk. A homlokzatok leírásánál a magtárablakok által kijelölt axisrendszert vesszük figyelembe. Az északi és déli homlokzat esetében az axisokat nyugat felől számozzuk 1-től 9-ig (az északi homlokzaton az 1-es számú axisban nincs magtárablak, ezt az eredeti nyílásrendszer első nyílása jelöli ki, amely belül az első emeleten világosan látható). A szinteket az épületkutatás alapját képező alakhü építészeti felmérés geometriai rendszerének $\pm 0,00$ szintjéhez - a magtárbejárat küszöbszintjéhez - viszonyítva adjuk meg. A barokk marionettszínház nézőterének padlószintje ebben a rendszerben $-0,44 \mathrm{~cm}$-nek felel meg.

\footnotetext{
${ }^{74}$ Landon 1962. i. m. p. 124.

75 Landon 1962. i. m. p. 124.

${ }^{76}$ Pohl II. p. 243. és Horányi 1959. i. m. p. 162., idézi Landon 1962. i. m. p. 124.

${ }^{77}$ Landon 1962. i. m. p. 124.

${ }^{78}$ Idézi Landon 1962. i. m. p. 124.
} 


\section{JELENLEGI ÁLLAPOT}

Az egykori marionettszínház - részben szerkezetileg nem kellően állékony volta, részben a magtárként való használat miatti terhek következtében - jelentősen deformálódott; az épület geometriája a parterre felé eső főhomlokzatnál és a hoszszanti falkoronák esetében számottevően szabálytalan.

Az épület jelenlegi formájában mintegy $13 \times 39$ m alapterületü, téglalap alaprajzú, nyeregtetővel fedett, mindkét végén oromzatos lezárású, tömegét a XIX-XX. század folyamán végzett átalakítások során nyerte. A lizénákkal tagolt homlokzatok kialakításánál felismerhető az egykori marionettszínház építészeti tagolása, de a homlokzatok a későbbi magtárrá alakítás miatt - különösen a két hosszoldalon jelentősen megváltoztak. Eredeti formáját leginkább a nyugati, íves oromzatos kialakítású homlokzat őrizte meg, nyílásait azonban később befalazták. Eredeti háromaxisos nyílásrendszere a mai állapotban is felismerhető, mivel középső kapujának kőkerete fennmaradt, szélső nyílásainak káváit pedig a korábbi falkutatás mind a külső, mind a belső oldalon feltárta.

A déli és északi homlokzatot meghatározó kilenc (illetve az északi oldalon a csatlakozó épületszárny miatt nyolc) axisba rendezett, két szinten elhelyezett, fekvő téglalap formájú magtárablakok a funkcióváltással kapcsolatos átépítéskor keletkeztek. Három ilyen ablak a nyugati homlokzaton is megjelenik. A déli homlokzaton ezeken kívül két - ugyancsak a későbbi használattal összefüggő - bejárat nyílik. A keleti homlokzat egyszerü, a fennálló tetőformához igazodó háromszögü oromfala az egykor a színház és a narancsház között álló víztorony XIX. század közepi elbontása után épült. A narancsházat és a marionettszínházat összekötő víztorony helyén utóbb igénytelen tárolót alakítottak ki, vasúti sínekből és kibetonozásból kis lejtésű tetőt képeztek a két végfal között. Ennek az összekötő épületnek ma már csak három hosszfala áll.

Az épület körüli terepszint az idők során jelentősen, mintegy $40 \mathrm{~cm}$-rel feltöltődött. A nyugati oldalon azonban a főhomlokzat és a hozzá csatlakozó földszintes épületszárny, valamint a tiszttartói ház nyugati homlokzatszakasza előtt a terepet több méter széles sávban rendezték, így ezen az oldalon a feltöltődés csak $10 \mathrm{~cm}$ körüli (nagyjából az eredeti küszöbszintig ér).

A mai egyszerủ nyeregtető födémekkel egybeépített, a magtár pillérrendszerével kombinált állószékes fedélszerkezettel épült. A belső teret a földszinten és az első emeleten két oszlopsor osztja három hajósra. A belső födémek a hosszirányú főtartókkal alátámasztott keresztirányú fagerendákon kétrétegü deszkázattal készültek (14. ábra). A belső faszerkezet anyaga vagy annak egy része másodlagos beépítésből származik. Több gerendán, oszlopon és könyökfán figyelhető meg más szerkezetre utaló ácskapcsolat kialakítása.

A déli homlokzat 4. axisában kialakított bejárathoz kapcsolódóan kb. másfél axis szélességben, az oszlopsorig tartó mélységben irodát választottak le a magtár 


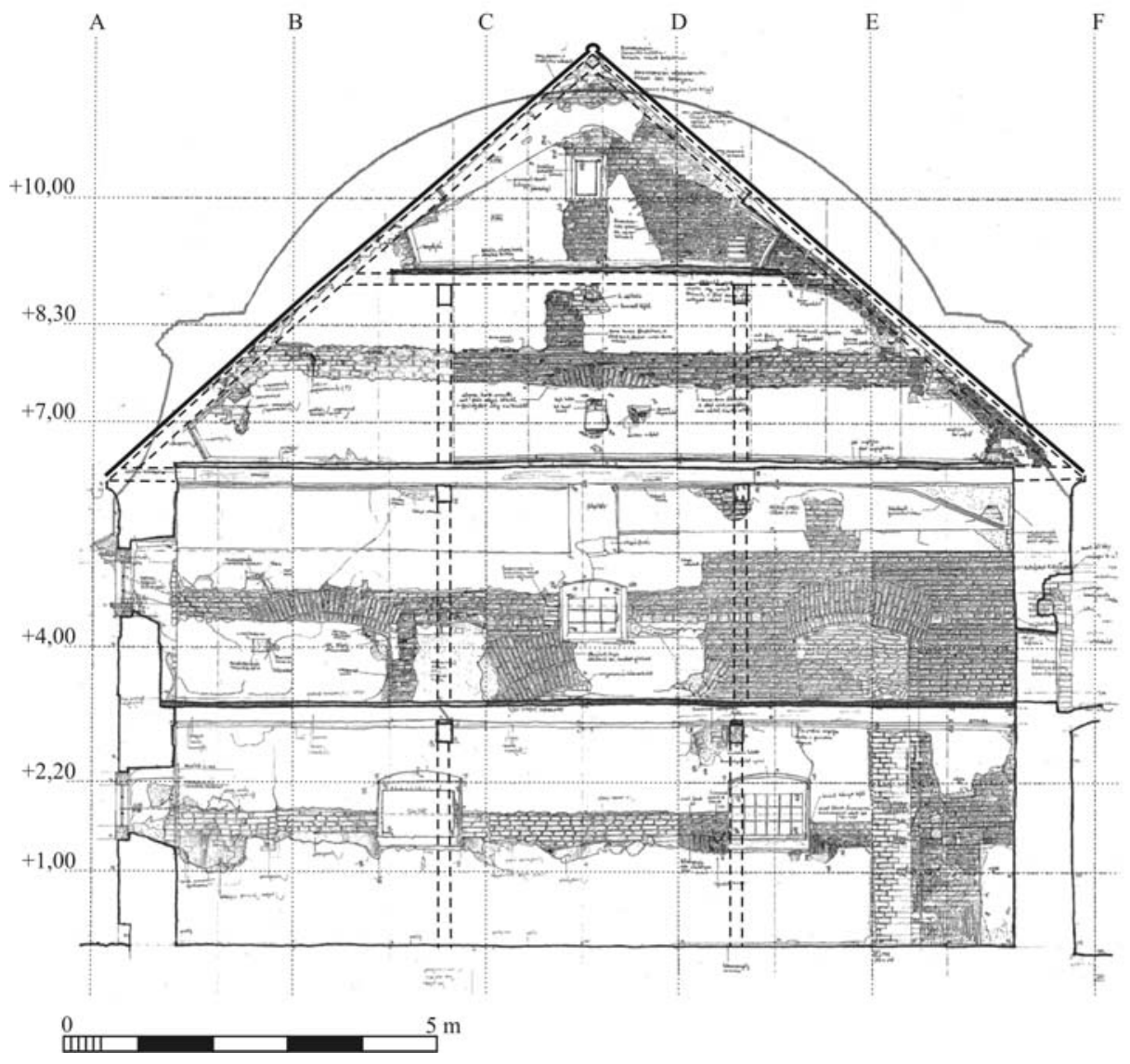

14. ábra. A magtár metszete a mai állapotban

teréből. A válaszfalakat tömör téglából falazták a födémig, melyet az iroda terében borított gerendafödémmé alakítottak. Az elfalazás és a belső faszerkezet kapcsolata arra utal, hogy az iroda az ácsszerkezet után készült.

A marionettszínház eredeti vakolata mind a külső, mind a belső falfelületeken jelentősen sérült. A belső felületen 1,6-1,8 m magasságig teljesen leverték, amikor az épületet - talán a XX. század első felében - belülről a téglára ragasztott bitumenes lemezzel és bitumenes kenéssel vízszigetelték. A homlokzatokon a talaj közelében - de helyenként akár 2 m magasságig is - a felnedvesedés folytán az idők során a vakolat levált és a téglafelületek is kifagytak. Nagy felületen pusztította el a még meglévő barokk vakolatot a korábbi falkutatás, melynek során a külső és belső falfelületeken is két, nagyjából $50 \mathrm{~cm}$-es sávban a vakolatot a falak teljes hosszában leverték. A belső felületeken - többnyire az ablakbélletek mentén - függőleges kutatósávokat is nyitottak. 
TÖMEGFORMA

Az épület jelenlegi alaprajzi kontúrja lényegében megegyezik a barokk marionettszínházéval (15. ábra). Számottevő változtatás ilyen tekintetben csak az épület keleti végén történt, a víztorony bontásával. A torony alaprajzi kontúrjára korábban az ismert ábrázolások alapján lehetett következtetni. Ezzel összhangban áll annak a falstruktúraváltásnak a vonala, amely a keleti végfalban mindkét oldalon a falsaroktól mintegy 170-180 cm-re megfigyelhető. A víztorony alaprajzi kontúrját a jelenleg is folyó ásatások igazolhatják.

Az épület eredeti formájában a falkorona a mai magasságnál mintegy $100 \mathrm{~cm}-$ rel alacsonyabb volt, $+5,45 \mathrm{~cm}$ magasságban helyezkedhetett el. Feltehetőleg az első átépítéskor (1845 után) magasították meg, annak érdekében, hogy a belső teret faszerkezetű közbelső födém beépítésével két raktárszintre oszthassák. Ez minden bizonnyal a víztorony lebontása után történhetett, mivel a keleti oldalon az oromfal és a felfalazás láthatóan egy ütemben készült. A felfalazás jellegzetes sárhabarcs kötőanyagú, így határozottan elkülöníthető az eredeti faltesttől. Vakolata ugyancsak eltérő: az eredeti barokk alapvakolatnál finomabb szemcse-összetételü, szürkésebb színú mészvakolat. A felfalazáshoz felhasznált tégla méretében és minőségében hasonló az eredeti barokk falban használthoz, lehetséges, hogy bontott téglát is felhasználtak. Ez származhatott a víztorony épületéből, vagy - kisebb mennyiségben - a marionettszínház esetleg még meglévő belső szerkezeteinek bontásából.

Az eredeti épületmagasságra további bizonyítékot szolgáltat a fópárkány helye. A kutatás során megállapítottuk, hogy a nyugati homlokzaton fennmaradt főpárkány az épület hosszoldali homlokzatain is végigfutott. A párkány befordítása a sarkokon már önmagában erre utal. A párkány magasságában azonban az oldalhomlokzatokon már sárhabarcsba rakott téglasorok húzódnak. A párkány függőlemeze alatti kímatag vonalában futó téglasort megbontva kiderült, hogy csupán fél tégla vastagságú pótlás készült itt sárhabarccsal falazva. Mögötte a fal belső rétegében még eredeti barokk falazóhabarccsal rakott téglasor fut. Ennek nyilvánvaló magyarázata, hogy a fal megmagasításakor a párkány kímáját formáló falsíkból kiálló téglákat eltávolították, és helyüket hosszában felezett téglákkal pótolták (16. ábra).

A párkány felső részét adó téglasorokat teljes egészében visszabontották, nagyjából +5,15 m magasságig, azaz a sárgerenda alsó síkjáig. Ebből kifolyólag az épület eredeti ereszkialakítására vonatkozóan kézzel fogható támpontunk nincs, csak analógiákra támaszkodhatunk. A legvalószínúbbnek az látszik, hogy az épületnek eredetileg nem volt ereszcsatornája.

Az eredeti épületmagasság a falak belső oldalán is követhető. A vakolat anyagában 4,90-5,10 m magasságban megfigyelhető változás és a legkorábbi festésrétegek határa is ebben a magasságban van - eddig verték le a vakolatot a falkorona 


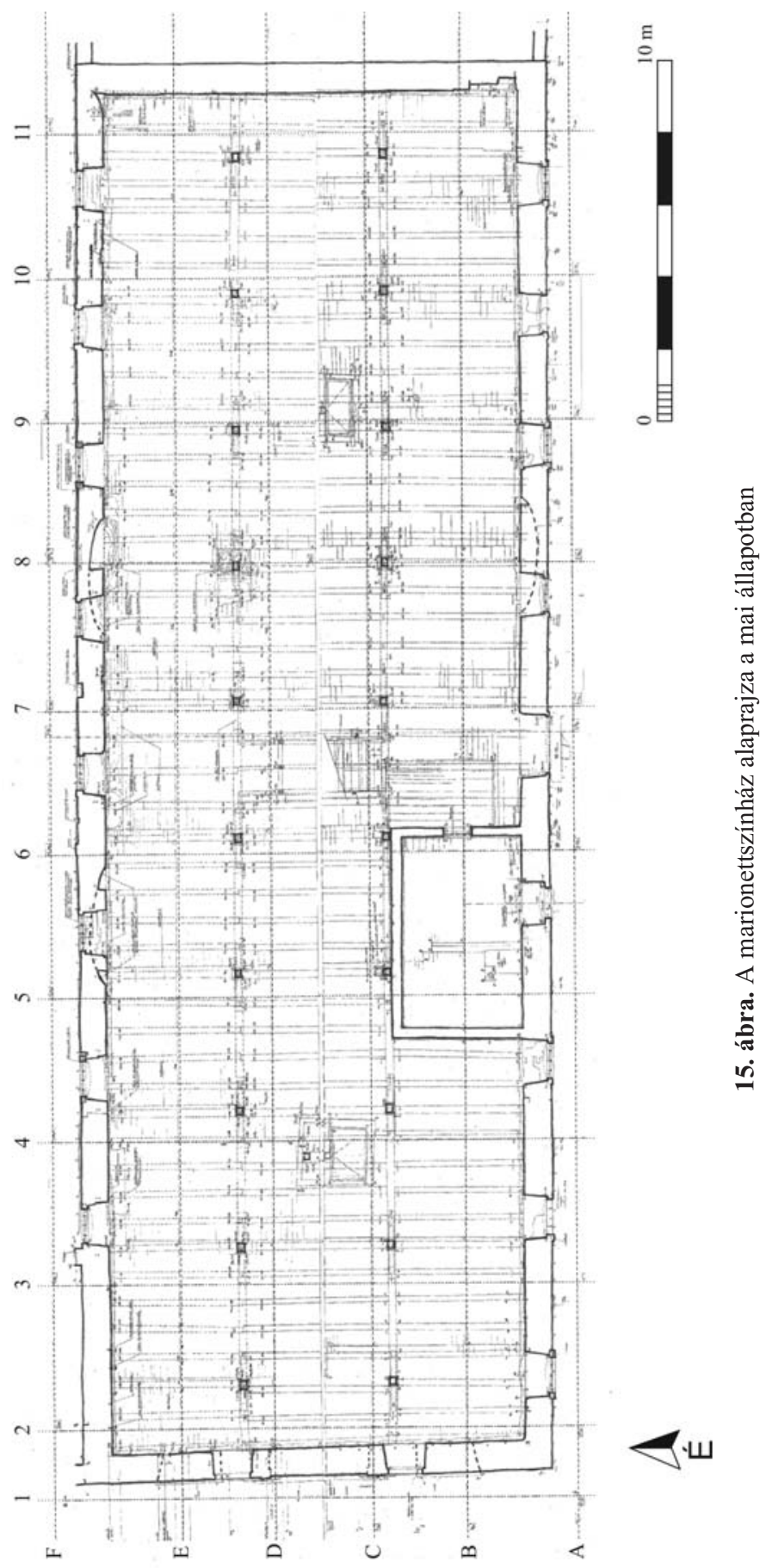




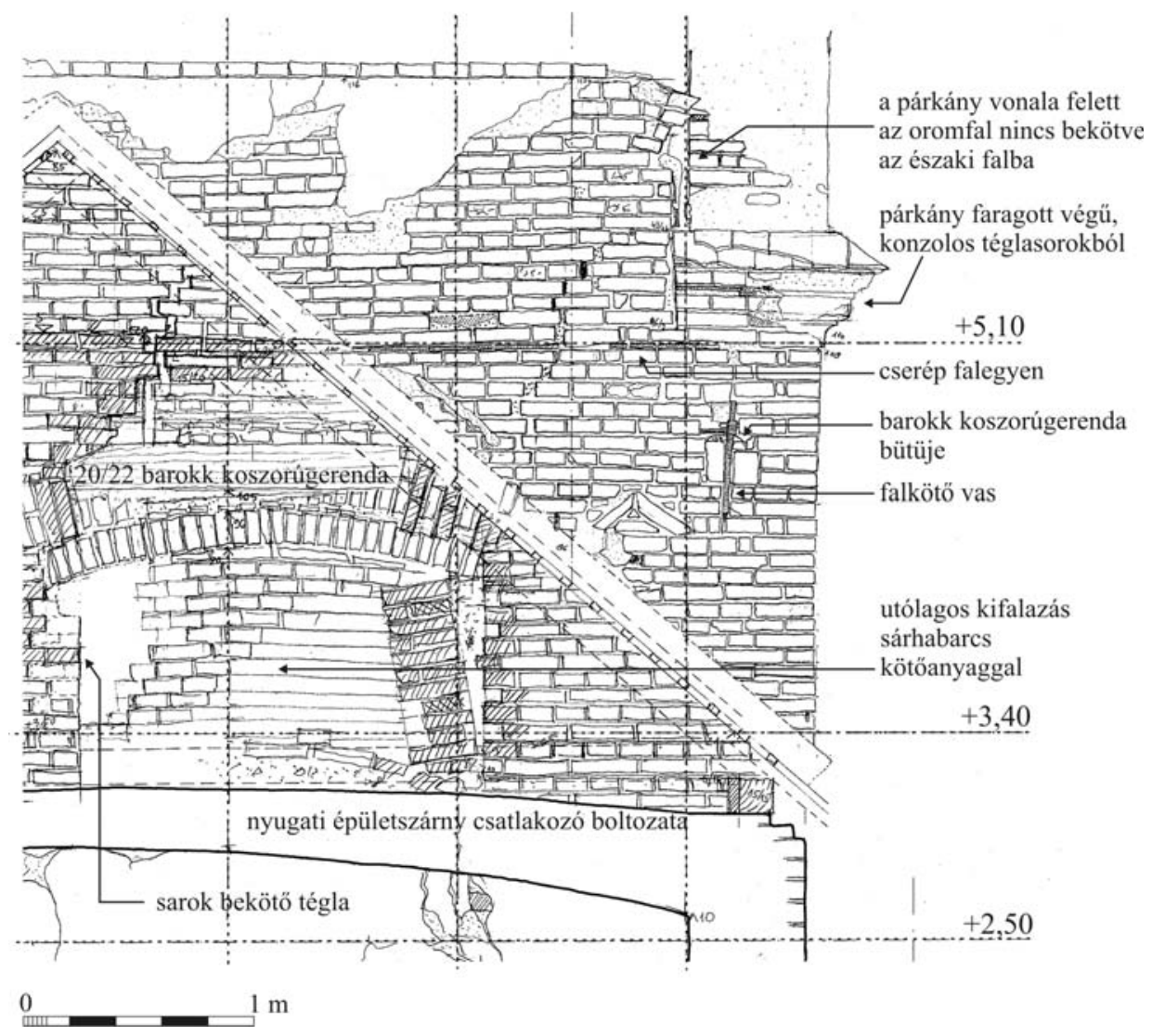

16. ábra. Az északi homlokzat nyugati végének részlete

visszabontásakor. Az épület északi falában, az északnyugati saroknál, a csatlakozó földszintes épületszárny padlásáról a sérült falszerkezetben az eredeti barokk koszorúgerenda is megfigyelhető. Ugyanezen épületsarkon az északi falban látható a nyugati falban húzódó koszorúgerenda bütüje. A fentiek ismeretében a részleges visszabontás és felfalazás ellenére a falkorona szerkezeti kialakítása is rekonstruálható.

A marionettszínház eredeti tetőformájára a legközvetlenebb bizonyítékot a nyugati oromfal belső oldalán találjuk. Az oromfal nagyrészt eredeti barokk formájában maradt fenn - erre külső tagozatai és falazatának anyaga egyaránt utalnak. A későbbi, magasabb tető lezárása érdekében az íves oromzat tetején kis háromszögű kiegészítés készült. A jelenlegi állapotban a legfelső magtárszinten látható a barokk kori tetőfedés csatlakozásának nyoma. Az oromfal egy, a ma fennál- 
ló tetősíknál laposabb és alacsonyabban záródó vonal mentén fél tégla vastagsággal elvékonyodik. Ez a vonal minden bizonnyal a barokk manzárdtető felső tetősíkjának lenyomata. A tetőlenyomat jobb oldalán egy rövid szakaszon az oromfal szegélyére felfektetett szélső cserépsor néhány darabjának töredékei is in situ megmaradtak. Úgy tünik tehát, hogy a manzárdtető a bontás előtti állapotban cserépfedésű volt, nem jelenthető ki azonban egyértelmúen, hogy ez a marionettszínház eredeti fedésével azonos. A tetőforma az - alább részletesen leírt módon kiszerkeszthető - valószínű tetőszerkezet segítségével rekonstruálható.

\section{SZERKEZETEK}

A marionettszínház alapozása téglából készült, a felmenő fal szélességéhez képest mindkét oldalon egy-egy fél téglával megnövelt szélességben. Az alapozási mélység a mai padlószint alatt $160 \mathrm{~cm}$-rel van. ${ }^{79}$ Az alaptestet feltételezéseink szerint elsősorban víz be- és kivezetésére szolgáló csatornák több helyen is áttörhetik, ezek a régészeti feltárás eredményeképpen válhatnak ismertté. Létükre azon leírások alapján következtetünk, melyek a vízcsobogókkal díszített grottaszerü belső dekorációról számolnak be. ${ }^{80}$

A XVIII. századiként azonosított felmenő falak kb. $80 \mathrm{~cm}$ vastagságú, jellegzetes barokk kori durva szemcsés adalékú mészhabarcsba rakott téglafalak voltak. A téglaméret egységes, nagyjából $29 \times 15 \times 7 \mathrm{~cm}$. A téglák egy részén bemélyített téglalap alakú mezőben domborodó $\mathrm{E}$ betűs pecsét látható.

Az eredeti falszerkezet az épület legnagyobb részén fennáll. Kivétel ez alól az északi fal keleti végén az első és második eredeti nyílásaxis (a magtár rendszerében az 1-3. axis) közötti falszakasz. Ezt pontosan nem tisztázott okból, feltehetőleg a magtárrá alakítással egy időben kibontották és újrafalazták, az eredeti falból csak egy 1-1,5 m magas tömb maradt meg zárványként. A bontás oka a szerkezet károsodott volta lehetett. ${ }^{81}$

\footnotetext{
${ }^{79}$ Az alapozási szint feltárását Andor Eszter statikus végeztette, az épület felújításával kapcsolatos tartószerkezeti vizsgálat keretében 2005-ben.

${ }^{80}$ A grottaszerü belső kialakításról és a dekoráció részeként megjelenő vízről több korabeli beszámoló is említést tesz az 1770-80-as években. Rélation des fetes données a sa Majesté L'Imperatrice, par S.A.M. le Prince d'Esterhazy, dans son Château d'Esterhaz. Le 1. et 2. 7-ber. Vienne, de l'Imprimerie Ghelen. 1773.; Korabinsky, Matthias: Almanach von Ungarn auf das Jahr 1778. Wien-Pressburg, 1778. pp. 324-327.; Korabinsky 1786. i. m. pp. 163-172.

${ }^{81}$ G. Györffi Katalin hivatkozik egy ismeretlen francia utazóra, akinek 1797-ben megjelent beszámolójából tudomásunk van arról, hogy eszterházai látogatásakor a marionettszínház már összeomlott. G. Györffy Katalin: Kultúra és életforma a XVIII. századi Magyarországon. Akadémiai Kiadó, Budapest, 1991. pp. 90, 152.
} 
A falszerkezetben köpenyezésnek, vastagításnak, megerősítésnek nyoma nem látható. A későbbi periódusban készült falszakaszok igen határozottan elkülöníthetőek, mivel sárhabarcsba rakott téglafalazatként épültek, és felületképző vakolatuk is a barokk alapvakolattól könnyen megkülönböztethető, finomabb adalékszemcséjű, szürkés színű mészhabarcsból készült. Ehhez a periódushoz köthető egyrészt az északi és déli fal felmagasítása, és az eredeti nyílások befalazása valamennyi homlokzaton. Ugyancsak idetartozó kiegészítés az északi fal említett kibontott szakaszának pótlása. Ekkor készülhetett a keleti oromfal kiegészítése a középső részen, a víztorony benyúló részének helyén. A felhasznált sárhabarcs kötőanyag, és az összefüggő falszakaszok szerves egybeépítése arra utal, hogy ezek a pótlások egy építési periódusban készültek. Nyilvánvaló, hogy ez csak a víztorony elbontása után volt lehetséges, és mivel az a korabeli ábrázolások alapján 1845ben még állhatott, ez az átépítés legkorábban a XIX. század közepén történhetett.

A keleti oromfal felső részén, az oromháromszögben, azaz az első padlásszint magasságától felfelé a falazat egyértelműen későbbi. Cementes habarccsal rakott kisméretű tömör téglából készült minden bizonnyal a XX. században, azaz legkevesebb fél évszázaddal a magtárrá alakítás és a torony bontása után. Ez a tény két lehetőséget vet fel. Egyrészt azt, hogy a magtárrá alakításkor épített oromfalat valamely ismeretlen - talán szerkezeti - okból le kellett bontani. A másik lehetőség az, hogy a magtárrá alakításkor ezen az oldalon még nem építettek oromfalat, hanem deszkaoromzatos lezárás készült. Az sem zárható ki teljesen, hogy a magtárrá alakításkor kontyolt formában zárták le a tetô keleti végét, ebben az esetben a mai oromfal építése csak egy jelentősebb tetőátépítéssel együtt történhetett. A ma fennálló tetőszerkezet építésének idejét egyelőre nem tudjuk pontosan meghatározni. A XIX. század közepénél előbb nem épülhetett. Valószínű, hogy a magtárfödémek szerkezetével együtt készítették, de ez utóbbiak esetében sem kizárt, hogy egy második raktárperiódushoz tartoznak. Ezt támasztaná alá a magtár Nagy Miksa által készített 1907 -es felmérése, ${ }^{82}$ mely az épület belsejében még nem 10, hanem csak 8 pár pillért ábrázol, a „b-c” jelü metszetrajzon pedig az épület keleti végén szarufákat, tehát kontyolt tetöt. (Megjegyzendő, hogy az említett rajz más tekintetben - például a nyíláskiosztást illetően - is meglehetősen eltér a mai állapottól, így megbízhatósága kétséges, 1. a 11. ábrát).

A nyugati és északi falban is megfigyelhetô az eredeti barokk koszorúgerenda, a nyugati oromfalban belülről a hosszában végigvezetett falkötő vas is látható. Az eredeti fedélszékből azonban mindent kibontottak. Geometriájára és szerkezetére a nyugati oromfal belső oldalán látható nyomok alapján lehet következtetni. $\mathrm{E}$

\footnotetext{
${ }^{82}$ Az Esterházy Süttöri uradalom épületleltára. Nagy Miksa, 1907 k. 4. granárium alaprajzai. A herceg Esterházy-család fraknói levéltára. Prot. 6091. Alföldy Gábor tájtervező kutatása és szíves közlése.
} 
nyomok értelmezéséhez és a tető szerkezetének rekonstrukciójához legközelebbi analógiaként a marionettszínházzal közel egykorú operaháznak a Beschreibungban közölt metszetrajzán (1. a 6. ábrát) ábrázolt szerkezetet vettük alapul. ${ }^{83}$

A tetőszerkezet sárgerendájának felső síkja - a korabeli gyakorlatnak megfelelően - a homlokzat fópárkányának tetejével lehetett egy szintben. A nyugati oromfalon megmaradt mindkét oldalon egy-egy falba bekötött, lefelé fordított ácskapocs. Ezek - az őket rögzítő habarcs tanúsága szerint - a marionettszínház építésekor kerültek a helyükre. Minden bizonnyal hosszirányú gerendák lekötései lehettek. Ezek a gerendák a manzárdtető felső kötőgerendájának gyámolítására szolgáltak, és oszlopokkal lehettek alátámasztva. A legfelső padlásszinten a manzárdtető kontúrja alatt a jobb oldalon gerenda csatlakozásának nyoma látható (bal oldali párja nincs feltárva). Ez minden bizonnyal ugyancsak az eredeti fedélszékhez tartozott, a felső szelemeneket gyámolító derékszelemen helyét mutatja. Ezt a derékszelement egyes állásokban a torokgerendára állított oszlopok támaszthatták alá.

A fenti ismert pontokból, és barokk kori ácsszerkezetek geometriáját alapul véve olyan szerkesztésű manzárdtető rekonstruálható, ahol a tetőcsúcs és a tetősík törésének pontja egy olyan félköríven fekszik, melynek középpontja a kötőgerenda felezőpontjában van, és amely koncentrikus az oromfal kontúrjával (17. ábra). A manzárdtető alsó és felső síkja közti töréspontok a félkörívnek a sugárral kimetszett harmadoló pontjaiban vannak, az eresz pontja az alapköríven kívül esik. A rekonstruált szerkezet ereszvonala a mainál $80-85 \mathrm{~cm}$-rel volt alacsonyabban. Kötőgerendájának alsó síkja kb. $+5,45 \mathrm{~m}$, a torokgerenda alsó síkja $+7,95 \mathrm{~m}$, a szaruzat csúcsa $+10,85$ m magasságban lehetett a felmérés rendszerében.

\section{SZÍNPADTECHNIKA}

A déli fal belső oldalán az emeleten a keleti faltól kezdődően nagyjából $20 \times 30$ cm méretü, 8-10 cm mélységü fészkek figyelhetők meg, $+4,40-4,45 \mathrm{~m}$ magasságban (18. ábra). Összesen tíz ilyen fészek azonosítható, közülük négy maradt épen - ezek belül is vakoltak és meszeltek -, a többit befalazott állapotban találtuk, néhány esetben létükre csak a falstruktúrából lehet következtetni. Kiosztásuk - amennyiben a 8. jelű axisban az utólag bevágott magtárablak helyén is feltételezünk egy közbülső, 11. gerendafészket - meglehetősen szabályos: 96-98 cm tengelytávolságra helyezkednek el. A ritmus csak két helyen bomlik meg, ott, ahol

\footnotetext{
${ }^{83}$ [Primitivius Niemitz] Beschreibung des hochfürstlichen Schlosses Eszterház im Königreiche Ungarn. Pressburg, 1784. № 7. kép. (Modern közlése: Mőcsényi 1998. i. m. CD B09.) Az új operaház metszetrajzán ábrázolt szerkezet felépítésében és szerkesztésmódjában egyébként megfelel a korabeli mintakönyvek manzárdtető-szerkezeteinek.
} 


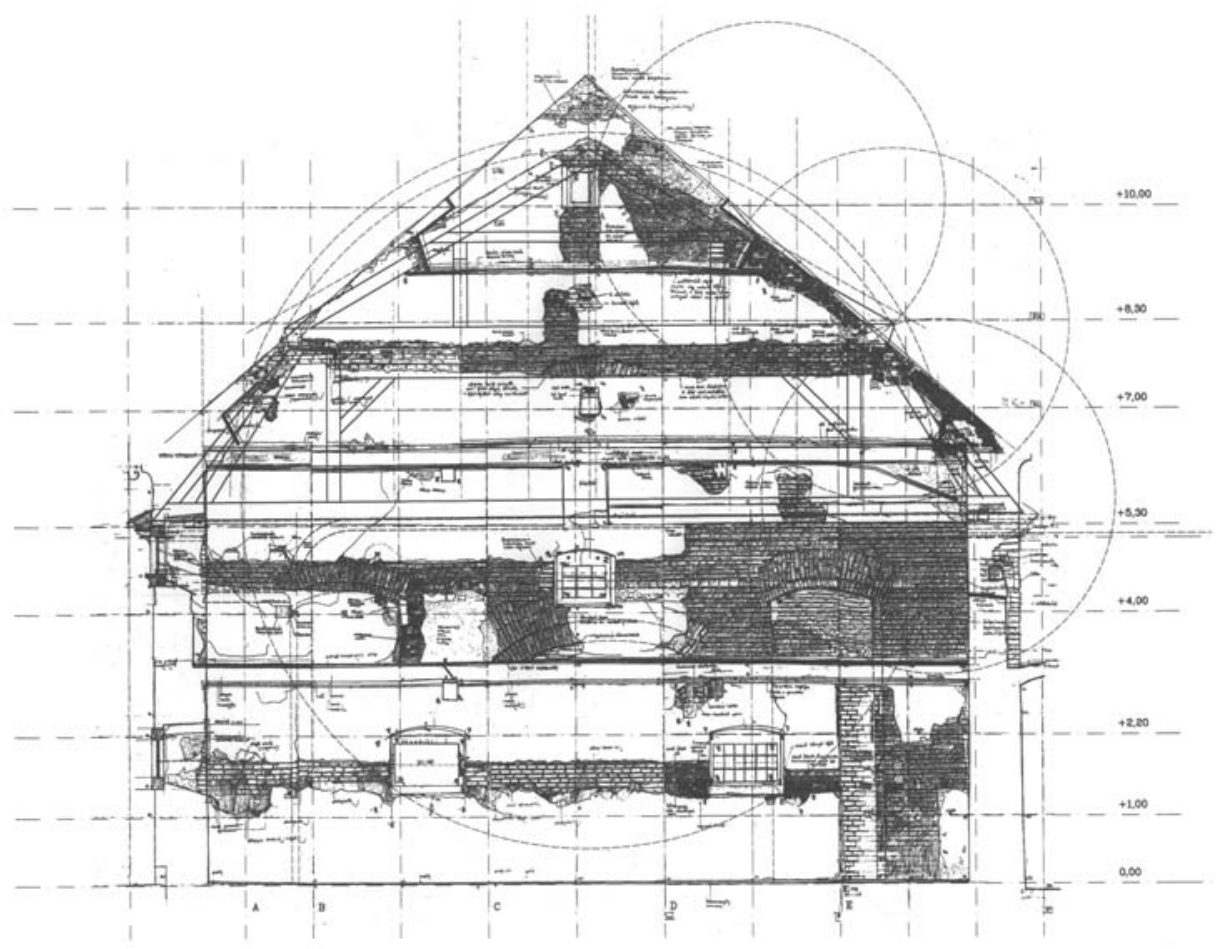

17. ábra. A barokk kori állapot metszetének rekonstrukciója

eredetileg nyílások törték át a homlokzatot. Itt valószínúleg csak a kiváltó ívek válla felett lehettek, a boltövet a záradéknál nem gyengítették, így a tengelytávolság a szomszédos fészkek között e két helyen 164, illetve $168 \mathrm{~cm}$. Párjaik minden bizonnyal az északi falban is megvoltak, de itt - a már említett három axis széles kibontás miatt - csak a keleti falhoz legközelebb eső kettő, és az utolsó (a 6. és 7. jelü axis közötti) maradt meg. Látható továbbá két fészek a keleti falbelső mindkét szélső szakaszán, amelyek a barokk periódushoz tartoznak. Ezek ugyancsak vakolt és meszelt belső felülettel maradtak fenn.

Feltételezésünk szerint ezek a gerendafészkek egy nagyjából $100 \mathrm{~cm}$-rel a tetöszerkezet kötőgerendája alatt elhelyezkedő, a színpadtechnikával összefüggésben álló gerendarendszerhez tartoztak. Korabinsky német nyelvủ leírásából ismert, hogy a marionettszínháznak színpadképek változtatására alkalmas kulisszarendszere volt. ${ }^{84}$ A Pauersbach tervezte szerkezet segítségével 36 változat volt megje-

84 „Die Figuren sind mathematisch verhältnissmässig mit dem Theater, welches 36 mahl plötzich verändert werden kan. Herr v. Pauersbach N. Oesterr. Landschafts Sekretär ist der Erfinder 
Krähling J. - Halmos B. - Fekete J. Cs.

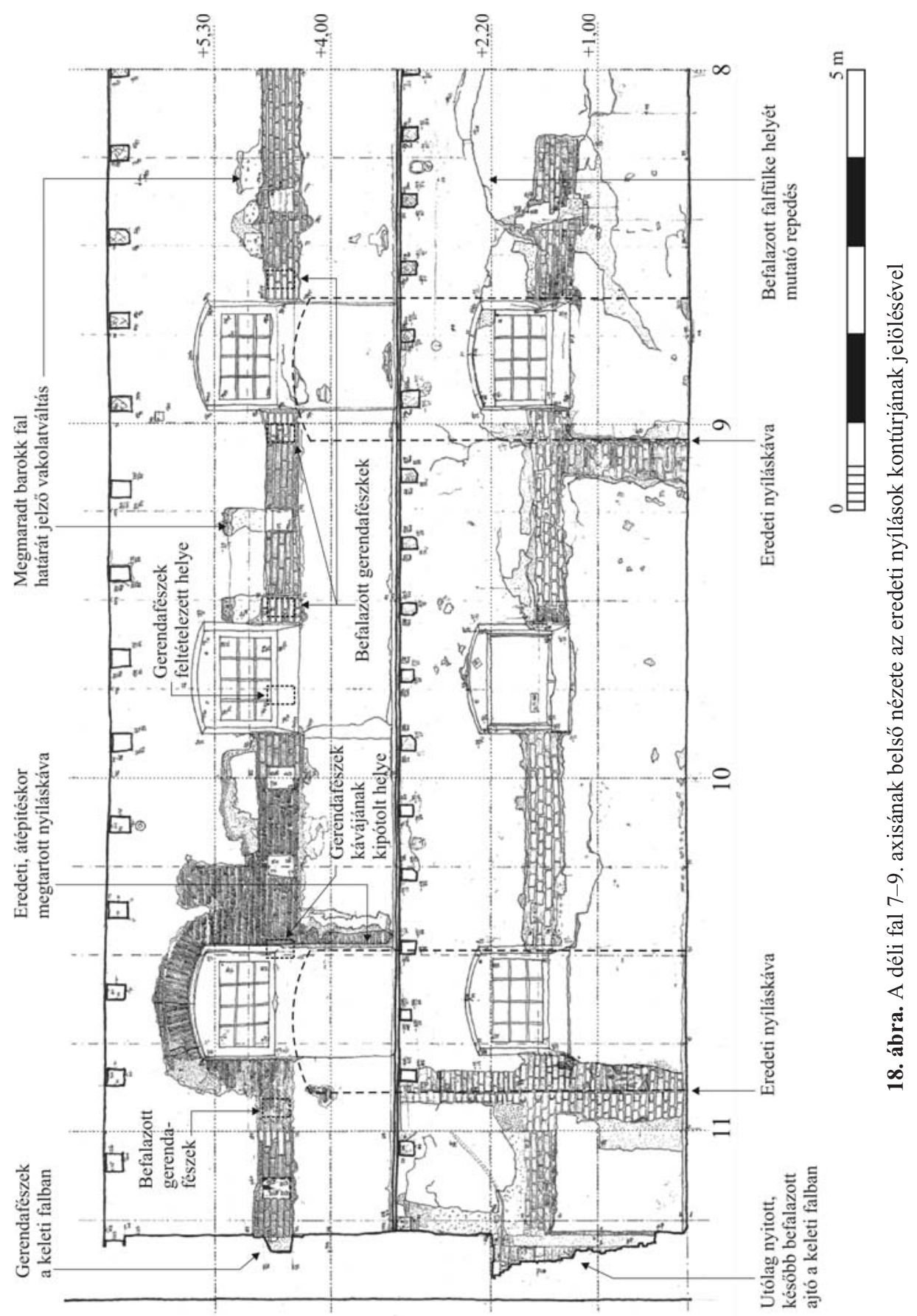


leníthető. A leírás leplezetlen lelkesedése a „masinéria” iránt azért sem meglepő, mert a barokk marionettszínház általában egyszerübb, dobozszerü szerkezet volt. Itt azonban - a barokk nagyszínházakhoz hasonlóan - oldalt kulisszákból, fölül sofitte-okból, hátul prospektből álló változtatható színpadképben mozoghattak a bábok. A rendszer elemeire és múködésére vonatkozóan a megkezdett régészeti feltárás adhat további támpontokat. A mai 6. és 7. jelü axis között elhelyezkedő szélső gerendafészek mindenesetre nagy valószínúséggel a színpad szélét jelölheti ki, nagyjából e legszélső gerenda vonalában húzódhatott a proscenium fal.

A belső falfelületek alsó részén a jelenlegi kutatás keretében elvégzett kiegészítő falkutatás ugyancsak felszínre hozott gerendafészkeket. ${ }^{85}$ A teljes feltárás és a gerendafészkek pontos bemérése előtt annyi valószínúsíthetö, hogy az épületnek lejtős színpada lehetett, amely a barokk színházakban a perspektivikus színpadkép kialakítása érdekében gyakori megoldás volt. A színpad feltételezhető széle mindenesetre nagyjából ugyanabban a vonalban jelölhető ki, ahol a felső gerendafészkek utolsó darabja is elhelyezkedik. A színpad szerkesztésére mérvadó, hogy a nézőtéren ülő személy látóhorizontja alatt legyen a színpad megemelt hátsó pereme.

A színpad előtt közvetlenül az ismert tervrajz ábrázolja a zenekar elhelyezésére szolgáló helyet. A barokk színházak esetében ez nem feltétlenül volt zenekari árok, előfordul olyan megoldás is, ahol a zenészek a nézőtérrel azonos szinten vannak elhelyezve. Egyelőre valószínübbnek tartjuk, hogy a fertődi színház esetében valódi zenekari árkot alakítottak ki. A régészeti feltárástól azt reméljük, hogy ha volt ilyen, azt mindenképpen felszíre hozhatja, hiszen az eredeti padlószintnél is mélyebben elhelyezkedő szerkezetek bontásának egy raktárrá alakítás során semmilyen ésszerü indoka nem lenne, azt valószínúleg csak feltöltötték volna.

\section{BELSŐ TÉR}

A színház nézőtere - a már említett írott forrásokra alapozva - grottaszerűen lehetett kialakítva, és tájképekkel, illetve szökőkutakat befoglaló fülkékkel díszítve. Az épület feltárás előtti állapotában erre utaló nyom egyedül az északi fal belső ol-

dieses werks. er hat über 20 Jahre darüber gedacht und es zur itzigen Vollkommenheit ausgeführt. Der Fürst kaufte ihm das Spiel um eine namhafte Summe ab unter der Bedingung, dass ers Jahr und Tag dirigiren sollte. Es ist prächtiger und genauer als des bekannten Nikola seines in Paris. die Maschinen dazu verdienen von ersten Maschinisten besehen zu werden.” Korabinsky 1786. i. m. pp. $163-172$.

${ }^{85}$ A Bauforschung módszere alapvetően nem támogatja a hagyományos vakolat-leveréses falkutatás alkalmazását. Ebben az esetben azonban a fal alsó részén a bitumenes falszigetelés készítésekor nyilvánvalóan eltávolították a barokk vakolatot. Ezért indokoltnak találtuk a felület téglafelületig történő tisztítását azokon a helyeken, ahol esetleges falbekötések vagy a színpadtechnikához tartozó elemekre utaló nyomok előkerülése várható az ábrázolások ismeretében. 


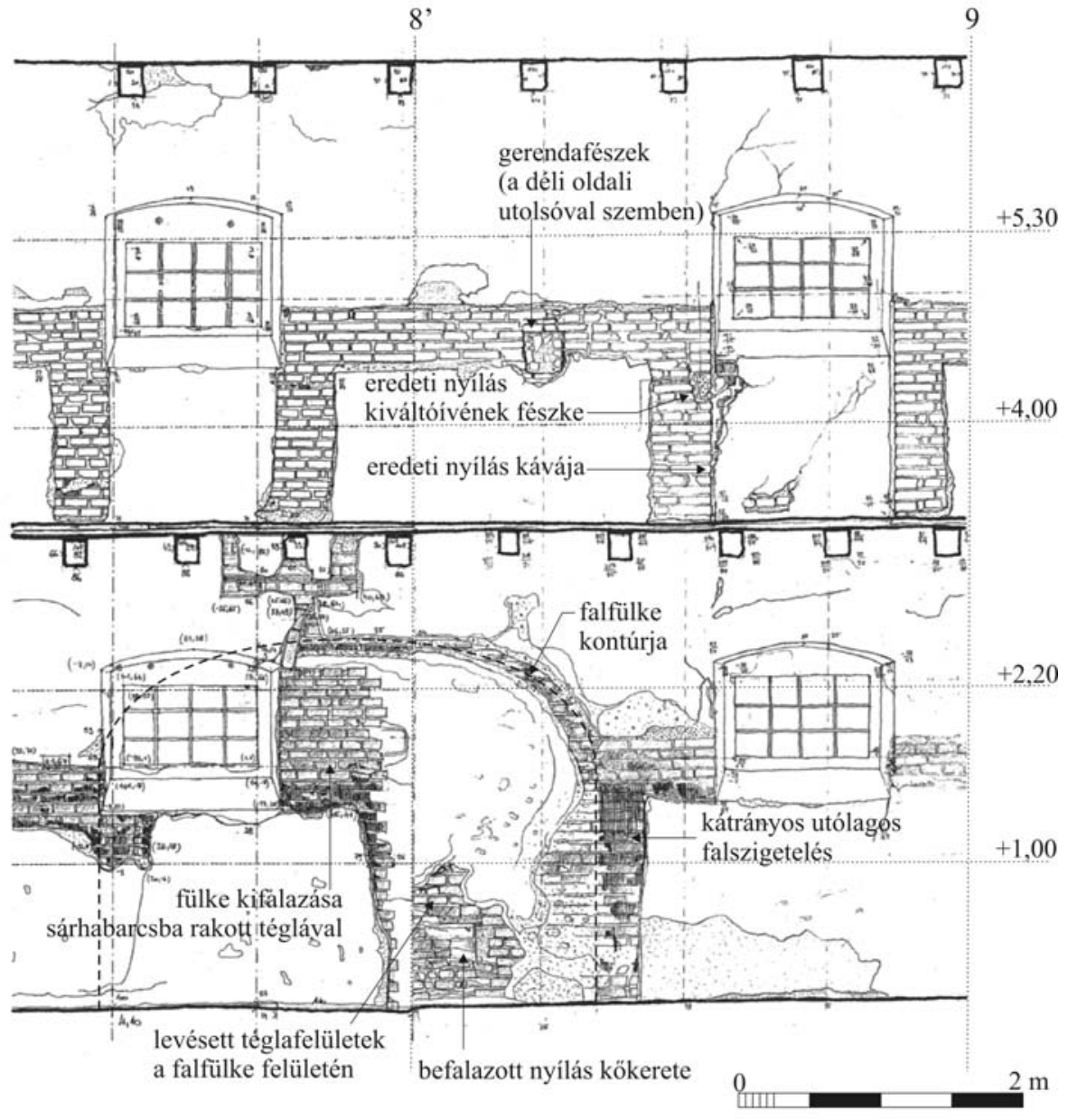

19. ábra. Az északi fal 6-7. axisának belső nézete az egyik belső falfülkével

dalán a 4. és 6., a déli fal belső oldalán a 6 . axis vonalában elhelyezkedő három falfülke. A fülkék szélessége megközelítőleg $360 \mathrm{~cm}$, magasságuk (a jelenlegi padlószinttől mérve) $280 \mathrm{~cm}$ (19. ábra). Elhelyezkedésükből és méretük azonosságából arra lehet következtetni, hogy egy negyedik is lehet, a déli fal 4. axisánál, vagyis az irodává alakított részen - ily módon szimmetrikus rendszer adódik. A fülkéket nem íves vonalban rakott téglasorokkal falazták ki, hanem utólag vésték az elkészült faltestbe, íves felső záródásuknál sem készítettek kiváltóívet. Ez azonban nem jelenti szükségképpen azt, hogy a fülkék utólag készültek, és nem tartoztak a 
marionettszínház eredeti állapotához. A bevésés magyarázata az egyszerübb építéstechnikai megoldás ${ }^{86}$ vagy építés közben történt koncepcióváltás is lehet.

Ezek a fülkék nyilvánvalóan összefüggésbe hozhatók azokkal a leírásokból ismert grottákkal, amelyekben kis szökőkutak vagy más dekorációk helyezkedtek el. Felmerül annak a lehetősége, hogy a fülkéket egyenesen a grottákkal lehetne azonosítani, belső felületükön azonban, ahol a korábbi falkutatás az utólagos befalazást kibontotta, semmilyen díszítés nyoma nem látható, csupán vékony, anyaga alapján minden bizonnyal barokk kori vakolat, és rajta egy-két réteg fehér meszelés. A már említett „Entwurff zu einem Fürstl. Winter Theater in Esterhaz” feliratú rajz alapján azt feltételeztük, hogy a grották nem itt helyezkedtek el, hanem mindkét oldalon egy-egy kelet-nyugati irányú falban, melyek a főfalaktól kb. $125 \mathrm{~cm}$ távolságra futottak (20. ábra). E falak létének bizonyítékát a nyugati fal belső oldalán feltárt északi oldalkapu kávájánál véltük felismerni. A nyílás kávájának feltűnő kónikus aszimmetriája már a felmérés kezdete óta feltünt, de a szabálytalan kialakításra nem találtunk magyarázatot. A falszerkezet felmérése és részletes lerajzolása során ismertük fel, hogy itt egy hosszanti bekötőfal lenyomatát látjuk, amely megerősítette azon feltételezésünket, hogy az ismeretlen „téli színház”-terv a kutatandó épületet ábrázolja. A bekötés szélessége alapján az említett fal csupán fél tégla vastag (azaz vakoltan is legfeljebb $20 \mathrm{~cm}$ ) lehetett. A grották helyét - a tervrajznak megfelelően - úgy képzeljük el, hogy azok ebből a falból hátrahúzott exedrákban lehettek, és legalább 60-70 cm mélységúek voltak. Ebben az esetben a grották mögött a párhuzamos falak közötti oldalfolyosó szélessége nagyjából 50 cm-re csökkent, vagyis a kényelmes közlekedés lehetetlenné vált. Ez - tehát a folyosó kiszélesítése - a magyarázata feltevésünk szerint annak, hogy a teherhordó falakban fülkéket kellett kialakítani. A megoldás ezzel együtt is lehet eleve tervezett - mert a belső tér szükséges legkisebb szélességéből és a teherhordó falak kívánt legnagyobb fesztávjából következően vált szükségszerúvé. Következtethetünk azonban egy építés közben bekövetkezett változtatásra is: a teherhordó falak építésekor még esetleg más kialakítású belső térrel számoltak, így a fülkék bevésésére ez utóbbi verzió szerint mégis utólag kerülhetett sor.

A belső tér díszítésére vonatkozóan egyelőre semmilyen nyom nem látható, de a régészeti felméréstől remélhető, hogy felszínre hoz egyes maradványokat, melyek alapján a díszítés jellege esetleg rekonstruálható lehet.

\footnotetext{
${ }^{86}$ A fülkét készíthették úgy is, hogy a falrakás megkönnyítése érdekében a sorokat szabályos téglakötésben rakták. Ahol a fülke ívének vonalvezetése megkívánta, a falat egyre kisebb vastagságban építhették, egy-egy újabb fél vagy egész téglával csökkentve a falvastagságot, a fülke felső részén pedig lényegében konzolos téglasorokkal álboltozatot alakítottak ki. Végezetül a kiálló felesleges téglasarkok levésésével alakították ki a fülke ívét. Ebben az esetben az építés eléggé gazdaságos, mivel viszonylag kevés vésésre volt szükség, és csak kis mennyiségű törmelék keletkezett.
} 

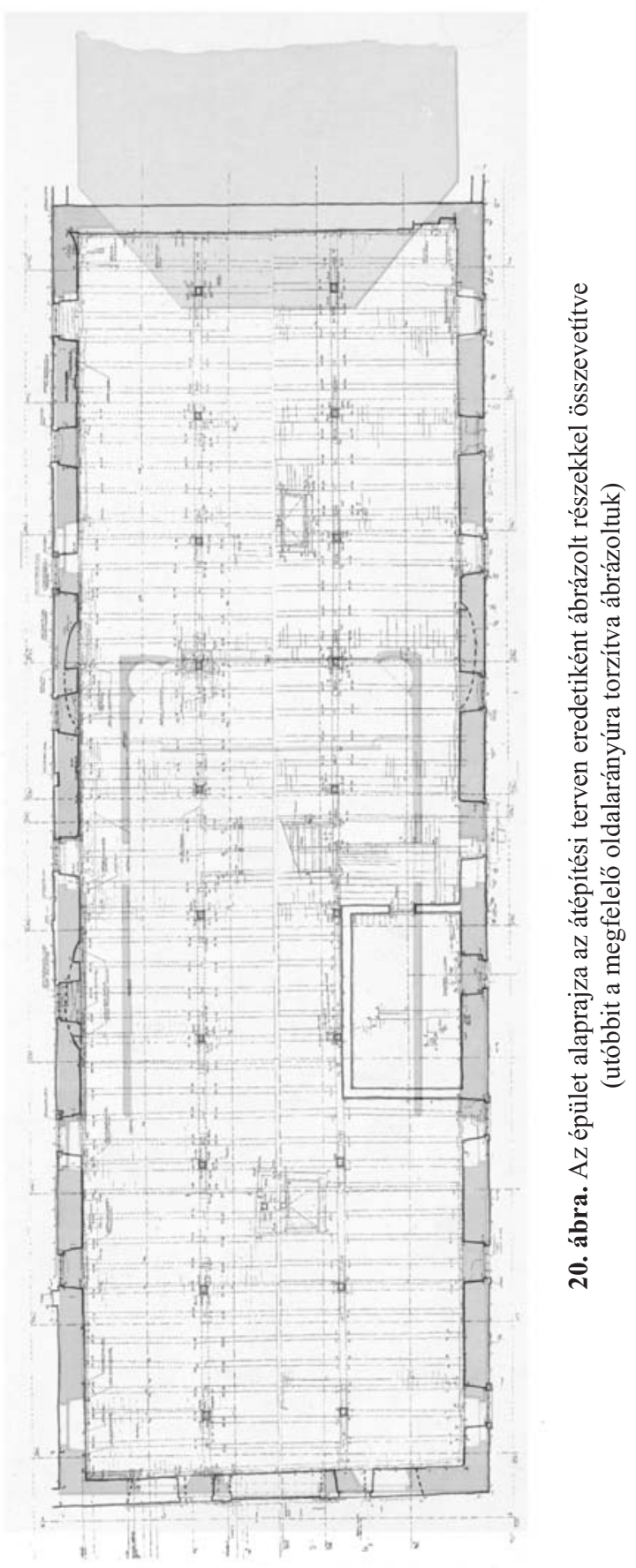


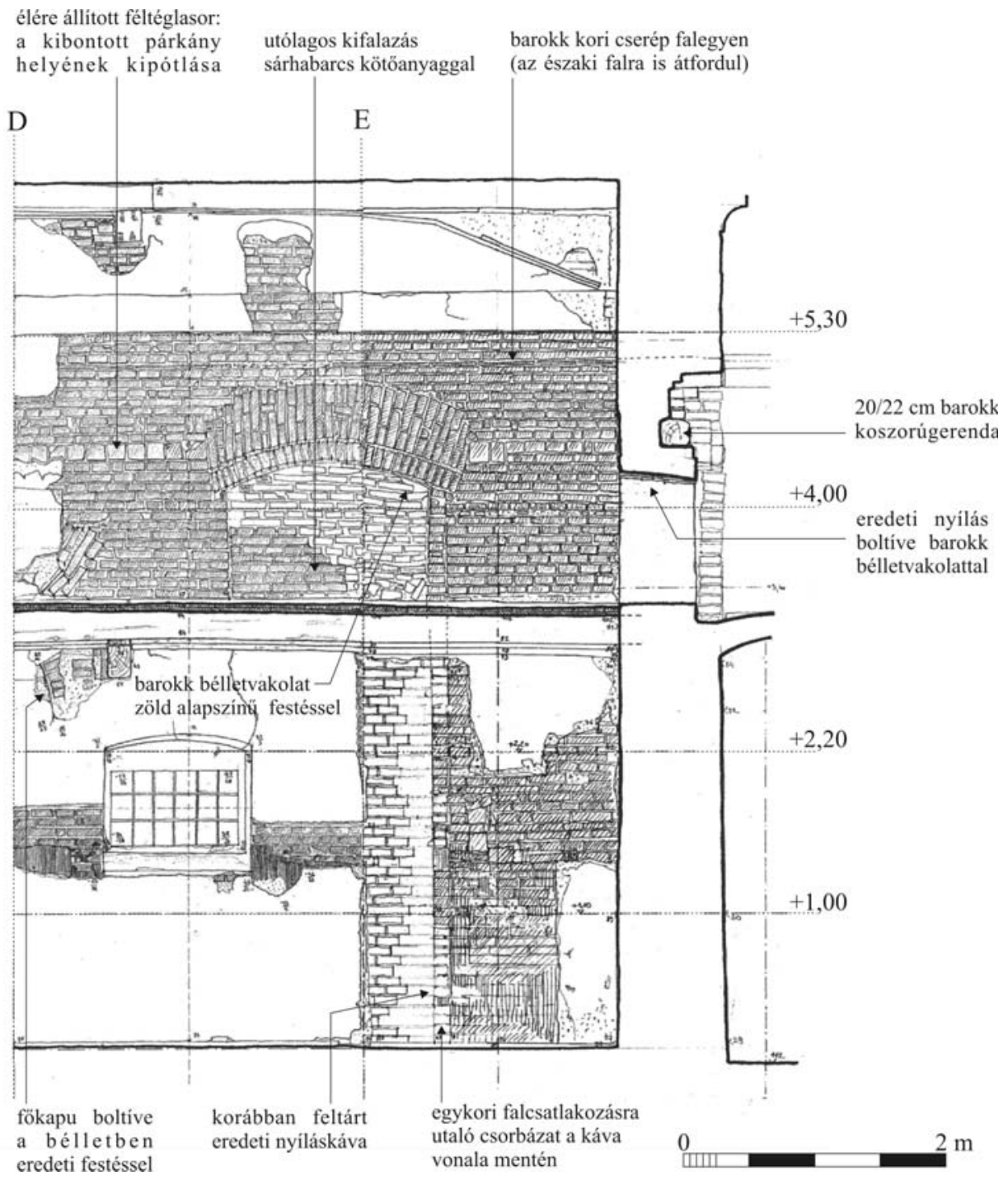

21. ábra. A nyugati falbelső északi oldala az északi fal metszetével

A átépítési terv a nézőtér előtt előcsarnokot mutat, de a kettőt elválasztó falat nem meglévőként, hanem tervezettként ábrázolja. Ez önmagában nem zárja ki, hogy a marionettszínháznak eredetileg is volt előcsarnoka, de egyelőre semmi kézzelfogható nyom nem utal rá. 
A belső tér lefedése a nyugati fal belső oldalán látható nyomok alapján rekonstruálható (21. ábra). A falon átlagosan 4,35 m magasságban élére fektetett téglákból álló sor figyelhető meg, egy téglasorral feljebb pedig eléggé szabályosan ritmusban (43-45 cm-es közökkel) álló féltéglák szakítják meg a falstruktúrát. Utóbbi elképzelésünk szerint egy faboltozat romenádjának bekötéseit mutatja, az alsó sáv pedig minden bizonnyal az egykori térlefedéshez tartozó párkány vonalát jelöli ki. Az élére állított téglasorok helyén a falsíkból konzolosan kiálló téglasorok lehettek, melyeket utóbb eltávolítottak. Ezek vakolatból húzott keskeny párkányt tarthattak. Erről indulhatott a faboltozat valószínüleg félkörös, ún. De l'Orme-féle deszkaíve. A feltevést alátámasztja, hogy a fa teknőboltozat-szerkezet (De l'Ormeféle boltozat) összeilleszthető (összeszerkeszthetö) azzal a fedélszékkel, mely a meglévő adatok alapján rekonstruálható. A boltozat vízszintes szakaszának deszkái a fedélszék kötőgerendáira lehettek szögelve. Ilyen szerkezetet mutat egyébként az ún. új operaház ismert metszete is.

Minthogy a nyomok csupán a nyugati falon maradtak fenn, nem egyértelmúen állapítható meg, hogy a fent ismertetett szerkezet csak az előcsarnok vagy a marionettszínház egységes belső terének lefedése volt-e. Az oldalfalakon nyilvánvalóan nem követhetőek a lenyomatok, hiszen a tér határa nem ez a fal, hanem a vele párhuzamosan futó belső válaszfal lehetett. Az oldalfolyosókat minden bizonnyal egyszerü borított gerendafödém zárta, melynek gerendái logikusan a faboltozat vállának magasságában lehettek. Ennek létét alátámasztó gerendafészkek azonban egyelőre sem az északi, sem a déli falon nem azonosíthatóak, így a kérdés tisztázása további kutatást igényel.

\section{NYUGATI HOMLOKZAT}

A főhomlokzat háromaxisos; horizontálisan lábazattal, tükrös falfelületekkel, feltehetően az oldalhomlokzatokon is körbefutó hármas tagolású föpárkánnyal, volutákkal közrefogott mezzaninszinttel, majd párkányra ültetett félköríves oromzattal tagolt volt. A faltükröket keretező lizénák az épület szélein duplázódtak (22. ábra).

A középaxisban váll- és záróköves kosáríves, kerékvetős kő keretelésű barokk kapu nyílott. A kapu zárókövét kettős kagylódísz ékítette. A főkapu fölött utólag magtárablakot nyitottak. A kőkeretet későbbi átfestések alkalmával szürke dörzsölt vakolattal látták el, eredetileg azonban minden bizonnyal nyers kőfelület volt. Festésnek, aranyozásnak nyoma az ékítményeken sem maradt fenn sehol, megjegyzendő azonban, hogy a keret teljes restaurátori feltárása még nem történt meg.

A kerékvető kialakítása arra utal, hogy lábazati kőburkolat kapcsolódhatott hozzá, vagyis: a marionettszínház fóhomlokzatán - a többi homlokzattól elté- 


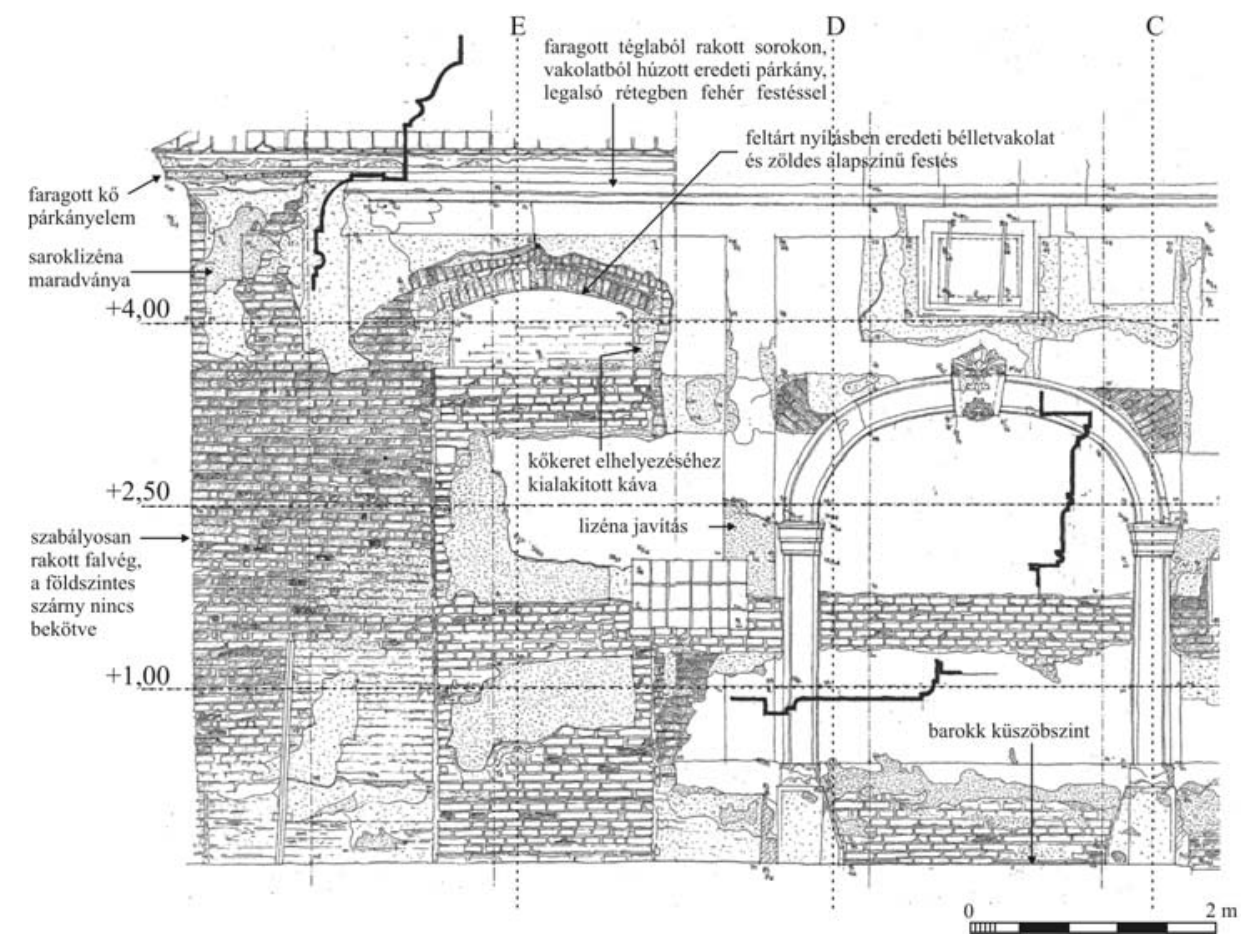

22. ábra. A nyugati homlokzat részlete - az északi és a középső axis

rően - kő lábazat lehetett. Ilyen kő lábazat esetén a kőelemek elhelyezése érdekében a falat a rendszerint kivésik. A kapuk között, és a szélső kapuk mellett a homlokzat széleiig valóban követhető ilyen falfelület, az azonban nem egyértelmü, hogy a fal szándékos levéséséról, vagy csupán - a többi oldalon is látható - kifagyásról van-e szó. Kérdéses az esetleges kő lábazat sarokmegoldása is, amelyrôl a falsarok erősen pusztult volta miatt nincs támpontunk. Elképzelhető, hogy a kerékvetőhöz hasonló sarokkő volt itt elhelyezve.

Az eredeti főhomlokzat két oldalsó nyílását a magtárrá alakításkor elfalazták. Ezek, valamint a kosáríves fóbejárat közé az alsó szinten egy-egy magtárablakot nyitottak. A két oldalsó nyílás egykor szegmensíves, kőkeretes lehetett, erre a részleges falbontás során kibontott falszövet utal. A kőkeretekből in situ nem maradt fenn semmi, létükre és formájukra csak következtetni lehet. A külső falsíkon jól látható, hogy a nyílások szélén itt a kőkeret elhelyezésére alkalmas hornyot alakítottak ki. E nyílások kávái a hosszanti tér közepe felé aszimmetrikusan, kónikusan bővülnek. A főhomlokzat mindhárom nyílásában in situ fennmaradt az eredeti küszöbkő. Szintje a jelenlegi bejárat küszöbszintjéhez képest $-44 \mathrm{~cm}$. 
A főhomlokzat főpárkánya három részből álló koronázó tagozat: lysisről induló kyma, függőlemez, és szima tagozat, tetején cserépsorral. A párkányt fedő többszöri átfestés rétegeinek restaurátori feltárása után bebizonyosodott, hogy a homlokzatot fedő eredeti festés nagy felületen fennmaradt. A vakolaton, melyből a tagozatokat kihúzták, jelentős javítás, pótlás nem fedezhető fel. A vakolat anyagának szemrevételezése is arra utal, hogy a párkányprofil a marionettszínház barokk kori építésének idejéből származik. A durva alapvakolaton finom simítóvakolatból húzott profil felületén a legalsó rétegben fehér meszelés látható. Ez a marionettszínház tagozatainak eredeti felületképzése lehet.

Ugyanez a - közvetlenül a barokk simítóvakolatot fedő - fehér mészfestés ismerhető fel a homlokzat más részein - mind a lizénák, mind pedig a faltükrök felületén. Feltételezető, hogy eredeti állapotában az épület homlokzatain homogén fehér mészfestés készültt. ${ }^{87}$

A mezzanin szint szélein lizéna, mellette feltételezhetően vakolatból formált voluta volt. Erre a faltest formájából, valamint a narancsház homlokzati kialakításából lehet következtetni. Az oromzat mezzanin szintjének középaxisában fekvő ovális ablak nyílt; ezt később a magtárrá alakításkor jórészt elfalazták, kerete azonban in situ, eredeti állapotában maradt fenn, csupán átfestették. A mezzanin szint zárópárkánya és az arra ültetett szegmensíves orommező zárópárkánya szintén hármas koronázó párkányelem, az épület fópárkányához hasonlóan. E második vízszintes párkány szélein feltehetően kővázák lehettek, de ennek nyomai már eltüntek, a váza vagy szobor téglaalapja azonban kivehető. Az orommező ívének tetején utóbb kis háromszögü toldás készült annak érdekében, hogy a ma fennálló, magasabb gerincű tetőt teljesen lezárják. A felső, álló téglalap formájú, vakolt szalagkeretelésű ablakot ugyancsak később vágták a falba, az orommezőben eredetileg nem volt nyílás. Az a kérdés, hogy az orommezőben valamilyen más - akár faragott, akár vakolatból kialakított - díszítés volt-e, a felület erősen pusztult volta miatt egyelöre nem eldönthetö.

\section{ÉSZAKI ÉS DÉLI HOMLOKZAT}

A marionettszínház két hosszoldali homlokzata lényegében azonos kialakítású, főpárkánnyal lezárt faltükrös-lizénás tagolású, ötaxisos, egyenletes nyílásritmusú, egyszintes elrendezésű volt.

Általánosságban elmondható, hogy az eredeti marionettszínház homlokzatainak lizéna-tagolása fennmaradt a felső vízszintes falisáv aljáig. A faltükröknek

\footnotetext{
${ }^{87}$ A homlokzat festésének feltárását Lángi József restaurátor végezte 2004-2005-ben. A restaurátori feltárás az épület egyes részeit illetően jelen cikk írásakor még folyamatban van, így ismereteinket új eredményekkel egészítheti ki.
} 
erre a vízszintes felső keretére ült egykor az elbontott oldalhomlokzati párkány, mely a nyugati homlokzat párkányával azonos magasságú és profilozású volt. A lizénákat a magtárrá alakításkor részben kijavították, a felső vízszintes tükörkeretet visszabontották és az új homlokzat architektúrájához illesztették.

A lizénák a hosszoldali homlokzatok keleti, víztorony felőli végein - a narancsházhoz hasonlóan - kettőzöttek lehettek. A saroklizéna egyik oldalon sem maradt fenn, mivel a magtár végső állapotában ez a lizéna már nem létezett. Az északi oldalon a falsarokról a vakolat már teljesen hiányzik, a déli homlokzat sarkán azonban a helyenként levált későbbi rétegek alatt a barokk alapvakolatban halványan kivehető egy függőleges sáv, ami az egykori lizéna kontúrja lehetett. A kettős lizéna mellett szól, hogy a narancsház homlokzatának az egykori víztorony felé eső vége is ilyen kialakítású. A homlokzatok nyugati végén csak délen maradt meg egy szélső lizéna, északon a csatlakozó épületszárny takarja az épületsarok alsó részét, a felső rész vakolata pedig teljesen elpusztult. Itt azonban nem valószínú a kettőzött lizéna, mert ezt a megoldást feltételezve a szélső axis nyílása nem az axis szimmetriatengelyében helyezkedett volna el, mint a többi axis esetében. A homlokzatokat eredetileg durva alapvakolattal síkra vakolták, majd ezen a felületen bekarcolták a lizénák helyét, és ezután újabb rétegben húzták fel a falisávokat. Ez a felső réteg több helyen levált, így utólag gyakran más vakolóanyaggal készült pótlások figyelhetők meg.

A déli oldalhomlokzat mai formájában kilencaxisos; két sorban magtárablakok tagolják - a 4. axisban irodabejárat, az 5. axisban magtárbejárat van. Utóbbit talán a magtárrá alakításkor, előbbit minden bizonnyal a XX. században nyitották, amikor a belső térből az irodahelyiséget leválasztották. Eredetileg a páratlan számú nyílásaxisokban szegmensíves, a feltárt kávák tanúsága szerint minden bizonnyal kőkeretelésű, az épület teljes magasságát átfogó nyílások voltak. A magtárrá alakításkor a kereteket eltávolították és a nyílásokat befalazták. Helyükre, valamint a köztes faltestek tengelyébe utólagos kiváltóívek beépítésével kívülről fekvő téglány alakú, belülrôl szegmensíves, rézsűs kávájú magtárablakokat építettek be. Az eredeti marionettszínházhoz tartotó szegmensíves nyílások kiváltó íveinek csak a fészke, illetve helyenként a boltváll néhány első téglája maradt meg, mert ezeket az emeleti magtárablakok megépítése miatt el kellett bontani. Ebből a kiváltóív vállmagassága $(+3,92 \mathrm{~cm})$, sugara, és így záradéka is rekonstruálható. A belső oldalon a déli fal 1. és 5. axisában látható a boltöv fogadófelülete. A külső oldalon a déli homlokzat elsô axisában maradt meg az eredeti kiváltó szegmensív válla néhány téglával, a 3. és 7. axisban pedig az eredeti nyílások hevederívének fogadófelülete látható (23. ábra).

Az északi homlokzaton (nyugat felől) az első axisnak megfelelő sávban nincsenek magtárablakok, mivel itt az épületegyüttes nyugati, földszintes összekötő szárnya kapcsolódik a színházhoz. Eredetileg ebben az axisban is készült a többivel 


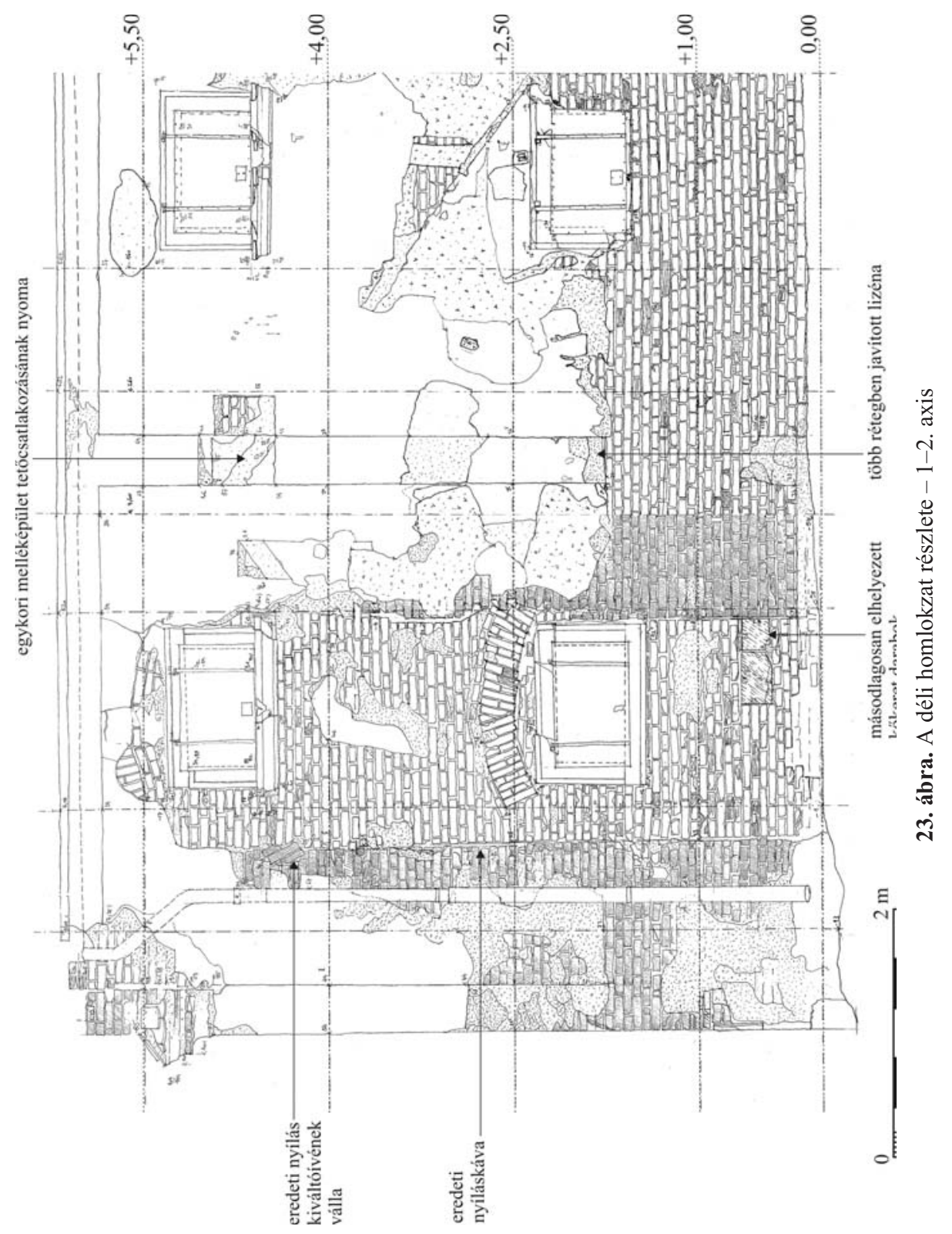


azonos méretű nyílás. Ezt a nyílást is sárhabarcsba rakott téglával falazták el, és rézsűs kávájának felületén megfigyelhető az eredeti vakolat. Ennek ellenére bejáratként hosszú ideig nem funkcionálhatott, vak ajtó lehetett. Valószínú, hogy az építkezés megkezdésekor érvényes eredeti terv szerint a két hosszoldali homlokzat azonos lett volna. Időközben azonban a koncepció kiegészült a marionettszínházat a tiszttartói házzal összekötő épületszárnnyal, és mire a színházat befejezték és átadták, a nyugati szárny is elkészülhetett. A két épületrész falazata egyértelműen elkülönül, nem egy építési ütemben készült. A színház felavatásakor, 1773-ban azonban már zárt udvarosnak mutatja az épületegyüttest az egykorú ábrázolás. A fenti feltevést valószínúsíti, hogy a nyugati szárny padlásteréből nézve a marionettszínháznak a tető alá eső homlokzatszakaszán nem találtunk vakolatmaradványokat. Ez a nyílás az egyetlen, ahol a kiváltó ív jelentős része épségben megmaradt, mivel itt nem vágtak bele magtárablakot. Sajnos azonban a korábbi feltárás a belső oldalon teljesen elpusztította a vakolatot, és a külső falsíkon a kávák is erősen sérültek, így a nyílás eredeti megjelenése nem pontosan tisztázható.

Az északi homlokzat többi axisában - a déli homlokzathoz hasonló módon - a nyílásokat befalazták, és matárablakokat nyitottak. Az eredeti kiváltó ívek nyomai itt is több helyen láthatóak. A külső homlokzaton csak a 3. axisban látszik a boltöv fogadófelülete, a többi axisban a vakolat ilyen magasságig nincs feltárva. A boltövből megmaradt tégla a belső oldalon sem látható, az indítást jelző ferde téglasorvégek azonban az 5., 7., és 9. axisban is megfigyelhetőek, utóbbiban a falazóhabarcson megmaradt a kiváltó első téglájának lenyomata az E betűs pecséttel.

A korábbi falkutatás mind az északi, mind a déli falban feltárta az eredeti nyílások káváját a belső oldalon. Ennek alapján megállapítható, hogy azonos szélességüek, a középtengelyre szimmetrikus rézsűs kialakításúak voltak.

A magtárablakokat részben másodlagosan felhasznált kőelemekből alakították ki. Az eredeti homlokzat nyílásaiban épített magtárablakok kőkeretesek, a közbülső falszerkezetbe utólag bevésett ablakok - hasonlóan egyszerü profillal vakolatkeretelésűek. Az első elfalazott nyílásaxis alsó részében a falazatban is látható egy kőkeret (szárkő) eleme. Az oldalhomlokzati nyílásokba befalazott másodlagos kőkeretek felvetik annak lehetőségét, hogy az oldalhomlokzat nyílásainak csak a kiváltó íve volt szegmensíves, az alatta lévő kőkeret viszont egyenes szemöldökú. A magtárablakok egyszerủen tagozott keretdarabjai között található szemöldökkövek azonban a marionettszínház nyílásainál szükebb nyílásokhoz tartozhattak, valószínű, hogy más épületből kerültek ide. Megjegyzendő továbbá, hogy az orangerie északi homlokzatának hasonló méretủ és ritmusú nyílásaiban in situ megmaradt kőkeretek is szegmensívesek, amelyekből - mivel a két épület egységesen volt kialakítva - arra következtethetünk, hogy a színházon is szegmensíves nyílások lehettek. Ugyanerre utal a főhomlokzat azonos vállmagasságú nyílásainak feltételezhető szegmensíves formája, amelynek párja az orangerie fó- 
homlokzatán in situ fennmaradt. A déli fal belső oldalának középső falfülkéje kibontásakor előkerült szegmensíves kőkeret-darab nagy valószínűséggel a marionettszínház egyik eredeti kőkeretéhez tartozhatott. Nem állapítható meg egyértelmúen, hogy az északi, déli, vagy a nyugati oldalon lehetett-e, azt mindenesetre alátámasztja, hogy a szegmensívesen kialakított falnyílásokban a kőkeret is szegmensíves szemöldökü volt - feltehetőleg valamennyi homlokzaton.

Az északi homlokzat 6. és 7. axisa között kisebb nyílás kőkerete került elő (belülről az északi oldal egyik falfülkéjének belsejébe esik - 1. a 19. ábrát), melyet utóbb sárhabarcsba rakott téglával falaztak ki az északi fal egyik belső falfülkéjével együtt. Ez a nyílás $85 \times 120 \mathrm{~cm}$ méretü, és a fal külső síkján elhelyezett, szabályos négyszög keresztmetszetüre faragott, de profilozatlan kő szalagkeretből van kialakítva. A keret szemöldökmagassága a magtár padlószintjéhez képest $+56 \mathrm{~cm}$ magasságban van, a keret alja pedig $-64 \mathrm{~cm}-\mathrm{en}$, azaz mintegy 10-15 cm-rel az egykori padlószint alatt. Kiváltására boltöv nem készült. Valószínüleg a kész falba vésték be ott, ahol a falfülke miatt a fal erősen elvékonyodik. Ennek ellenére elképzelhető, hogy a nyílás a marionettszínház eredeti koncepciójának része vagy legalábbis még a színház funkció megőrzése mellett történt átalakítás eredménye. A belső régészeti feltárás igazolta, hogy a nyílás egy mélyebb padlószintü, esetleg a zenekari árokkal összefüggő oldaltérbe vezetett. Rendeltetése egyelőre nem tisztázott, erre a kérdésre a teljes külső és belső régészeti feltárás adhat választ. Véleményünk szerint a külső homlokzaton - a többi nyíláshoz hasonlóan - nyers felületü kőkeretként jelent meg.

A déli oldalon, a nyugati faltól számított első és második ablakaxis között tetőlenyomat látható, amely alatt nagy felületen található barokk kori vakolat. A tető valószínűleg a magtárrá alakításnál is később készült provizórikus épületrészé lehetett.

A hosszoldali homlokzatok párkánya - mint azt korábban tárgyaltuk - a nyugati oldali fópárkány folytatása volt. Közvetlenül a párkány magassága alatt mindkét oldalon az épület teljes hosszában megfigyelhető egy fekvő cserépsor. Ez az a falegyen, melyet akkor készíthettek a kőmúvesek, mikor az építkezést átadták az ácsoknak. Ebben a magasságban feküdhetett a tetőszerkezet talpgerendája, így ez a falegyen is az eredeti épületmagasságot bizonyítja. Erre a vízszintezett falkoronára épült a tető ácsolása után a főpárkány, melyet a falmagasításkor visszabontottak.

Az oldalhomlokzatokon az épületnek egyszerü vakolt lábazata lehetett. A mai küszöbszint felett 5-6 cm magasságig (tehát az eredeti járószint felett kb. $50 \mathrm{~cm}$ magasságig) a falsík 3-4 cm-rel kiugrik. Az ily módon kialakított lábazatra felhordott lábazati vakolat - a régészetileg feltárt szakaszokon - csak nyomokban maradt meg, így felületére, esetleges profilozására, festésére vonatkozóan nincs támpontunk. Ugyancsak a külső feltárás hozta felszínre a déli oldal 7. axisában az ere- 
deti nyílás küszöbkövét. Valószínú, hogy az északi és déli homlokzat valamennyi kapujánál ilyen küszöb készült, és ezek ma is eredeti helyükön lehetnek.

\section{KELETI HOMLOKZAT}

Az épület keleti homlokzatának nagy részét eredetileg a csatlakozó nyolcszögü víztorony foglalta el, melyről a korábban kifejtettek szerint korabeli ábrázolások alapján feltételezhető, hogy más a színház építését megelőzően is itt állt. A víztoronyhoz észak és dél felől csatlakozó 170-180 cm széles falszakaszok az eredeti fópárkány magasságáig megmaradtak, falazatukban határozottan elkülönülnek a víztorony bontása között készült, sárhabarccsal rakott középső résztől. Az eredeti fópárkány vonala felett itt is sárhabarcsba rakott falmagasítást találunk. Ez felveti annak lehetőségét is, hogy a keleti oldalon a tető kontyolt volt. Az is elképzelhető azonban, hogy a torony bontásakor és az új oromfal felépítésekor a régi csonka oromfalból megmaradó két oldali keskeny háromszöget nem elég állékony volta miatt lebontották. Az ábrázolások között nem találunk olyat, amely ezt a kérdést minden kétséget kizáróan eldöntené.

Az egykori víztorony melletti falszakaszban ma mindkét oldalon befalazott nyílás nyomai láthatók. Az északkeleti sarokban lévő bejárat kiváltó boltövének indítása in situ fennmaradt. Az ajtó déli oldali kávájának nem marad nyoma, de feltehetőleg egészen a víztorony faláig tartott. Ezt a nyílást - feltételezhetően helyszüke miatt - úgy alakították ki, hogy a belső sarokban az északi (hosszanti) falba a saroknál ívesen bevésve lekerekítették, így több hely maradt az ajtó számára. A lekerekítés az egykori épületből fennmaradt teljes magasságban látható. A nyílásnál megfigyelhető további kiszélesítés nyoma, mely arra enged következtetni, hogy a magtárrá alakítás után használták még. A keleti fal déli oldalán a sarokban ugyancsak nyílást találunk, melyet alighanem a XX. század elején falazták el. Az ajtó legalább az 1920-as évekig fennállhatott, és csak azt követően falazták be, hogy a magtárba bevezették az elektromos áramot. Az elektromos vezetéket ugyanis a délkeleti sarokban nem egyenes vonalban, a falat áttörve húzták át a marionettszínházat a narancsházzal összekötő melléképületbe, hanem a nyílás kiváltó ívének vállához levezetve, feltehetőleg a - mára eltávolított - ajtótok sarka mögött. A nyílás bélletének szerkezete lefaragott téglafelületü; a szegmensíves kiváltó íve pedig a barokk kori falszerkezettől eltérő habarcsolású. Ezekből feltételezhető, hogy e nyílás később készülhetett, tehát az eredeti marionett-színháznak még nem volt része. A kiváltó ív olyan falszakaszra támaszkodik, amely sárhabarccsal falazott, tehát a magtárrá alakítás időszakára tehető. Nem zárható ki teljesen, hogy ebben a sarokban is volt eredetileg egy hátsó bejárat, azonban ha volt is, csak a ma látható elfalazott nyílásnál kisebb lehetett. 


\section{NYÍLÁSZÁRÓK}

A marionettszínház épületének egyetlen nyílászárója sem maradt fenn eredeti helyén. Egyértelműen azonosítható darabjukat (pánt, vasalat stb.) a régészeti feltárás sem hozta felszínre. Rekonstruálásukat tovább nehezíti, hogy az átépítések során - a nyugati homlokzat főbejáratát kivéve - valamennyi nyílás kőkeretét is eltávolították, így rögzítési pontokat sem ismerünk. A nyílászárók tekintetében így kénytelenek vagyunk a kevéssé részletgazdag ábrázolásokra és analógiákra támaszkodni. A nyugati főkapu keretének teljes feltárása szolgálhat újabb információval, különösen az ajtószárnyak rögzítésével kapcsolatban. A tartószerkezeti szakvélemény a nyílások kibontását a falszerkezetek megerősítése előtt nem javasolja.

Feltételezzük, hogy a nagy méretü homlokzati nyílások kőkerettel nem voltak megosztva. Középen felnyíló ajtószárnyaik lehettek, melyek a nagy magasság miatt talán nem teljes magasságban egyben nyíltak, hanem alsó és felső részre osztottak lehettek.

A szomszédos narancsház in situ fennmaradt kőkeretein látható csaplyukak arra engednek következtetni, hogy ott a külső síkra fa zsalugáterek voltak felszerelve. Ezek meglétét a marionettszínház esetében is feltételezzük.

Maguk az ajtók a kőkeret belső síkjára felszerelt, befelé nyíló, osztott üvegezésü szárnyakkal készülhettek. Feltételezésünk szerint a déli, északi és nyugati homlokzat azonos méretű ajtói azonos megjelenésűek és szerkezeti kialakításúak lehettek.

\section{ÖSSZEGZÉS}

A fertődi Esterházy kastélyegyüttes egykori marionettszínháza a XXI. század kezdetén végre megkapta azt a figyelmet, melyre az európai barokk színházak történetében betöltött szerepe szerint méltó.

A Budapesti Múszaki és Gazdaságtudományi Egyetem Építészettörténeti és Múemléki Tanszéke által alkalmazott Bauforschung-módszer segítségével sikerült újabb - az egykori eredeti állapotra, valamint az átépítés periódusaira vonatkozó - nyomokat rögzíteni a fertődi egykori marionettszínház épületén. Így további számottevő beavatkozás nélkül egészíthettük ki jelentős mennyiségü adattal azon ismereteinket, melyekkel a korábbi falkutatás szolgált.

A kutatás eddigi eredményeinek ismeretében az épület homlokzatainak és tömegformájának hiteles rekonstruálására mindenképp vállalkozni lehet. Ebben a tekintetben elsősorban a víztorony megjelenésére vonatkozó adataink hiányosak, az ásatástól azonban várható a torony alapfalainak feltárása, ily módon annak pontos pozíciója és alaprajzi kontúrja rögzíthetővé válna. 
A feltételezhető egykori térlefedő- és tetőszerkezet felszerkesztésével, valamint a barokk kori padlószint ismeretében a belső tér arányait is rekonstruálhatjuk. A belső tér kialakítására, elrendezésére vonatkozóan a legfontosabb támpontunk egyelőre a tanulmányunkban sokat emlegetett átalakítási terv. Kutatásunk egyik legfontosabb eredménye annak a feltevésnek az igazolása, hogy ez a terv az egykori marionettszínház épületére vonatkozik, és több mint valószínú, hogy az ábrázolt formában nem valósult meg. Ez fontos támpontot jelent a régész munkatársaink által megkezdett hitelesítő ásatás számára, melytől a belsőre vonatkozó feltevéseink igazolását várjuk. S talán joggal reméljük azt is, hogy leleteik a sokat csodált belső díszítés jellegére és a kortársakat ámulatba ejtő „masinéria” müködésére vonatkozóan is szolgálnak adalékokkal, s így még közelebb juthatunk az egykori bábszínház hiteles elvi rekonstrukciójához.

\title{
NEW INTERPRETATION OF THE MARIONETTE THEATRE IN FERTŐD - WITH ADOPTION OF BUILDING ARCHEOLOGY (“BAUFORSCHUNG”) AND A TRUE-TO-FORM ARCHITECTURAL SURVEYING AS A RESEARCH METHOD
}

\section{Summary}

\begin{abstract}
The marionette theatre and the performance of puppet operas in Fertőd (or Eszterháza, as it was called in the $18^{\text {th }}-19^{\text {th }}$ century) was an important attraction of the European palace culture. The activity of the patron duke Miklós Esterházy and the outstanding artists and masters of his court like Joseph Haydn and Karl Michael von Pauersbach ennoble the marionette theatre to be an unrivalled piece of the cultural heritage of Hungary. The pomp and unique formation of the theatre built in 1772-73 was unanimously admired by the contemporary travellers. The building had lost its original function at the end of the $18^{\text {th }}$ century already, then after 1845 it had been transformed into a granary in several steps and was threatened by total destruction by the end of the $20^{\text {th }}$ century. The scientific research aiming the reconstruction of the building was started on the authority of MÁG in 2004. The work on the spot was carried out following the method of "Bauforschung" (Building Archeology) making possible the detailed analysis of the building causing the least damage possible. One important scientific result of the true-to-form architectural survey was in proving the identification of a building shown on a reconstruction plan from 1789 with the marionette theatre of Fertöd. The analysis and documentation of the characteristics of the wall structure, the different layers of paint and plaster made it possible to determine the different periods of construction, and to outline the formation of mass, space, facades and structures of the original $18^{\text {th }}$ century building. Further research - verifying archaeological excavation first of all - may be able to provide information about the rich inner decoration and the machinery of the stage known in historic descriptions.
\end{abstract}

Keywords: Baroque Architecture, architectural history research, Building Archaelogy, theatre architecture, marionette theatre 
